\title{
THE GROWTH STAGES OF THE LOPHOPHORE OF THE BRACHIOPODS PLATIDIA DAVIDSONI (EUDES DESLONGCHAMPS) AND P. ANOMIOIDES (PHILIPPI), WITH NOTES ON THE FEEDING MECHANISM
}

\author{
By D. Atkins, D.Sc. \\ From the Plymouth Laboratory
}

(Text-figs. I-23)

The lophophore of Platidia, as illustrated in most memoirs and text-books, bears little resemblance to its appearance in life, no doubt because such illustrations and the accompanying descriptions were based on dried specimens. The lophophore of Platidia has been considered to be of a peculiar sigmoid type, differing from that of any other known lophophore. The dredging by R.V. 'Sarsia' of three species of the genus in recent years has afforded the opportunity of figuring the lophophore in its natural state, and the working out of its growth stages in $P$. davidsoni and $P$. anomioides: these were previously unknown for any species of Platidia. The third species, a new one, is described separately (Atkins, 1959).

Although $P$. anomioides (Philippi) is the type species of the genus, $P$. davidsoni (Eudes Deslongchamps) is considered first as it was the first to be dredged by R.V. 'Sarsia' and work on it was ready for publication when $P$. anomioides was obtained in May 1958.

All figures have been drawn with the aid of a camera lucida.

\section{PLATIDIA DAVIDSONI (EUDES DESLONGCHAMPS)}

A species of Platidia dredged by R.V. 'Sarsia' from off Penmarch and the north coast of Spain is evidently P. davidsoni (E. Deslongchamps) as it agrees with the description of that species by Eudes Deslongchamps (1855) in having 'small spinous asperities' on the outer surface of the ventral valve, although these are often confined to a submarginal zone, and in some individuals apparently worn and indistinguishable. Fischer (1872, I873) noted of this species that 'elle porte quelquefois des aspérités assez nombreuses'. The brachial support agrees with the figures accompanying E. Deslongchamps's paper, but not with his description. There appears to be some confusion over its actual state. In his description of his new species, Morrisia (=Platidia) davidsoni, E. Deslongchamps (1855) described the 'apophysary system consisting of two lamellae originating at the base of the sockets, and 
united to a small elevated process or septum which arises from near the centre of the valve'. In the accompanying figure (pl. $\mathrm{x}$, fig. $20, c, d$ ) prongs at the apex of the septum are described as 'broken lamellae attached to the summit of the septum'. The prongs were evidently considered to be part of the descending and not of the ascending branches. It may be surmised that he found the branches as figured but assumed that they had been broken.

Fischer in 1872 and again in 1873 said of the brachial apparatus 'que nous n'avons pu obtenir entier, pas plus que $M$. Deslongchamps'.

Davidson in 1887 (p. I 55) stated: 'Interior of the dorsal valve not completely known. Short cylindrical processes project into the interior of the shell from a little under each angle of the wide semicircular foramen, and from about the middle of the bottom of the valve arises a thickened pillarshaped process or septum, curved toward the hinge, and forked at its extremity'. On the following page he mentioned that 'in Platydia davidsoni these principal stems, in the specimens examined by M. E. Deslongchamps, Dr Fischer, and myself, were either broken or absent; so that to ascertain their real condition more specimens will have to be examined hereafter'. Curiously enough Fischer \& Oehlert in I89I stated briefly 'appareil brachial comme dans le $P$. anomioides' and figured the brachial support as being exactly the same (pl. viii, fig. $15 b, c$ ) with the descending branches complete. It is difficult to understand their failure to mention that in previous descriptions by one of them (Fischer, 1872, I873) and by Davidson (1887) the descending branches were described as either broken or absent.

The difference in the brachial support of the 'Sarsia' specimens and those of Fischer \& Oehlert (I89I) would not seem to be a size difference: their specimens had a length of $6 \mathrm{~mm}$ and width of $6.5 \mathrm{~mm}$, whilst of my two largest $P$. davidsoni, one was $7.8 \mathrm{~mm}$ long and $7.2 \mathrm{~mm}$ wide and the other $7 \mathrm{~mm}$ long and $8 \mathrm{~mm}$ wide. In the 'Sarsia' specimens there is no doubt that the brachial support is as described and figured by Davidson in I887. The absence of descending branches joined to the septum is not due to the fracture of extremely delicate branches in animals allowed to rot in sea water and then the remains blown out of the shell with a pipette. In a specimen $5.4 \mathrm{~mm}$ long and $6.9 \mathrm{~mm}$ wide which was sectioned, there is no indication of lateral outgrowths from the septal pillar other than the forked processes at the apex. In brachial valves with lophophore intact cleared in cedar wood oil or oil of winter green the same state of development was found.

It is not impossible that better development of the brachial support may occur in local varieties. However, as previous to Fischer \& Oehlert's I89I paper all authors had agreed that the descending branches in this species were either incomplete or broken, it would appear that their 'Travailleur' and 'Talisman' specimens need re-examination.

Platidia davidsoni was dredged in some numbers by R.V. 'Sarsia' in February and July 1956 and in June 1957 from a small area of yellow coral, 
Dendrophyllia cornigera Lamarck, off the Point of Penmarch at a depth of 45 to 48 fathoms. Two individuals, one $4.2 \mathrm{~mm}$ long and $6 \mathrm{~mm}$ wide and the other $2.7 \mathrm{~mm}$ long and $3.4 \mathrm{~mm}$ wide, were taken attached to a very large species of oyster off the north coast of Spain in position $43^{\circ} 42^{\prime} \mathrm{N}$., $3^{\circ} 58^{\prime} \mathrm{W}$. at a depth of 220 fathoms.

In the Penmarch area the Platidia were attached to the dead region of the growing coral and to the brachiopods Terebratulina retusa and Megerlia truncata, themselves fixed to the coral. They generally occurred on the lower brachial valves of the brachiopods in no definite position. Four P. davidsoni of shell length 0.8 to $2.7 \mathrm{~mm}$ were attached to the brachial valve of an adult Megerlia.

An occasional individual was found standing more or less erect on its hinge, with organisms encrusting both valves, but generally, when the animal is not feeding, the lower, brachial valve is closely applied to the substratum and when this has sharp irregularities the valve may be almost punctured. The brachial valve is thinner than the ventral, is generally approximately flat, but may be concave on coral. When situated where a slender side branch of coral arises the shell may show a well-marked artificial sulcus (see Fig. II) where it extends on to the side branch.

The shell of $P$. davidsoni is frequently irregular in shape, owing to the irregularities of the coral and to the proximity of other growth. Occasionally when attached to the valve of another brachiopod the shell may be regular; an example was one near the anterior edge of the brachial valve of a Terebratulina and facing in the same direction. It was subcircular, $6 \mathrm{~mm}$ long and $7 \mathrm{~mm}$ wide, and regularly domed: half of its ventral valve was encrusted by a polyzoan. Irregularity in shell shape is accompanied by asymmetry in varying degree of the lophophore and sometimes by that of the gonad.

The mantle edge is produced into tiny lobes, and bears setae; in small individuals they reached a length of $0.6 \mathrm{~mm}$.

Two spots of carmine pigment are present, probably in connexion with the preoesophageal ganglion. These pigment spots are difficult to distinguish, being masked by spicules: in some individuals they appear to be absent. They could not be found in P. anomioides and in a new species of Platidia (Atkins, 1959), both of which were taken in deep water. Carmine spots have also been found by me in certain other brachiopods.

From one $P$. davidsoni, $5.4 \mathrm{~mm}$ long, $6.9 \mathrm{~mm}$ wide, sectioned, with small gonad, it would seem that this species is hermaphrodite: the gonad was mostly male, with tailed sperm in the posterior region, but with a few small ova. From examination of entire specimens, however, it appears that ovaries and testes develop at different times, so that the animal appears dioecious. The ripe ovaries are dark orange and visible through the semi-transparent shell; the entire animal is orange tinted. The testes are of a less dark and more pinkish orange than the ovaries. $P$. davidsoni in the laboratory tanks retained their colour for about a month, but had lost much of it, especially from the 
filaments, after 2 months, possibly as a result of semi-starvation. Other brachiopods so far known to be hermaphrodite are Argyrotheca (see Senn, 1934) and Pumilus antiquatus (Atkins, 1958).

The gonads of $P$. davidsoni were large in February, June and July; specimens were not obtained at other times of the year.

\section{GROWTH STAGES OF THE LOPHOPHORE AND ITS SUPPORT}

During development the lophophore passes through the usual growth stages, trocholophous, schizolophous and zygolophous, culminating in a somewhat modified plectolophe.

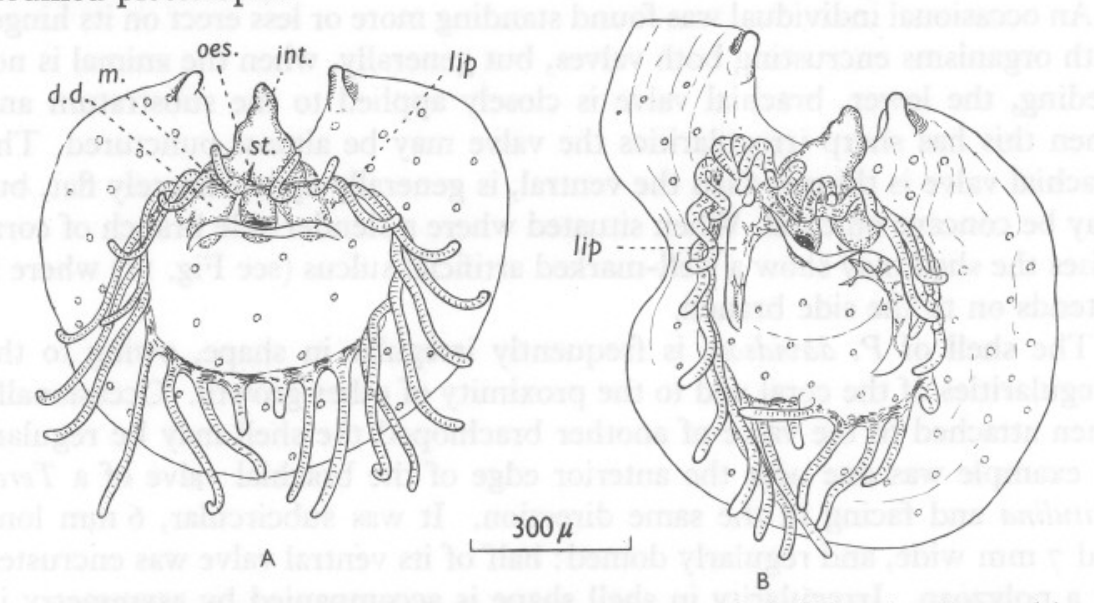

Fig. I. Platidia davidsoni. Brachial valves of specimens of shell length $0.8 \mathrm{~mm}$ (A) and I.O mm (B) with trocholophes, to show the growth of the lip of the food groove (lip) in front of the mouth $(m$.): drawn living. In both individuals filaments are in single series. Spicules are present where indicated in the filaments and brachial membrane. Mantle caecae shown. In this and following figures mantle setae have been omitted. d.d., digestive diverticulum; int., intestine; m., mouth; oes., oesophagus; st., stomach.

The trocholophous lophophore is of the broad-based terebratellacean type. The smallest individual obtained, of shell length $0.8 \mathrm{~mm}$ and width $0.9 \mathrm{~mm}$, had the lophophore in this stage: the lophophoral ridge was a complete circle. Eleven filaments were present on the left and twelve on the right (Fig. IA). These were set low on the mantle, except for those behind the mouth which arose from the body. The lip of the food groove extended but a short distance on each side of the mouth. Spicules were present in the filaments and at their bases, but not elsewhere.

An unusually long-stalked, irregularly shaped individual of some I $\mathrm{mm}$ diameter, in the late trocholophous stage, had I4 pairs of filaments in single series: a few on the right were abnormally short. The lip had extended much further than in the smaller individual and two pairs of spicules were present in the brachial membrane(Fig. I B). These two specimens shown in Fig. I illustrate clearly the 
manner of growth of the lip of the food groove by lateral growth from a small preoral lobe, and not as an invagination of the rapid extension of the region between the latest formed filaments of the trocholophe (see Williams, I956, for use of term) as described by Percival (1944) in Terebratella inconspicua.

At a shell length of $\mathrm{I} \cdot 4 \mathrm{~mm}$ and width of $\mathrm{I} \cdot 5 \mathrm{~mm}$ the lophophore was very slightly indented anteriorly: seventeen pairs of long filaments with ridged frontal surfaces were present in single series, and two pairs of minute buds. The lip of the food groove had now extended to the bases of the last long filament on each side. The number of spicules in the brachial membrane was two on one side and one on the other, so that some variation in the time of formation of these spicules evidently occurs.



Fig. 2. Platidia davidsoni, of shell length $\mathrm{I} \cdot 4 \mathrm{~mm}$, width $\mathrm{I} \cdot 7 \mathrm{~mm}$. Brachial valve with early schizolophe, drawn living. Differentiation into a double series of filaments had begun, the first outer grooved filament on each side is indicated $(g$. $f$ l. $)$. The filaments behind the mouth are almost erect. The spicules supporting the lophophore have increased in size and numbers.

At a shell length of $\mathrm{I} \cdot 4 \mathrm{~mm}$ and width of $\mathrm{I} \cdot 7 \mathrm{~mm}$ the lophophore was early schizolophous with twenty-one pairs of long filaments and in addition three pairs of minute buds (Fig. 2). Differentiation of filaments had begun with three outer grooved filaments on the right and two on the left anteriorly. The spicules in the brachial membrane had increased in size and complexity.

The arrangement of the spicules at the base of the lophophore in an individual $\mathrm{r} .8 \mathrm{~mm}$ long is shown in Fig. $3 \mathrm{~A}$. At this size no septum could be distinguished in a valve with lophophore in position. 
The trocholophe and early schizolophe are bell-shaped in the feeding position, the filaments are directed upwards and outwards (Fig. 3B): it is only in the contracted state that they are directed inwards.

A more advanced schizolophous stage of shell length $2.0 \mathrm{~mm}$ and width $2.3 \mathrm{~mm}$ is shown in Fig. 4A, and the appearance looking down into the gaping shell of a similar stage in Fig. 4B. The brachial skeleton first appears at about this size in the form of a low septum, with tiny divergent lamellae, having the appearance in ventral view of a small transverse boss. That it represents small,
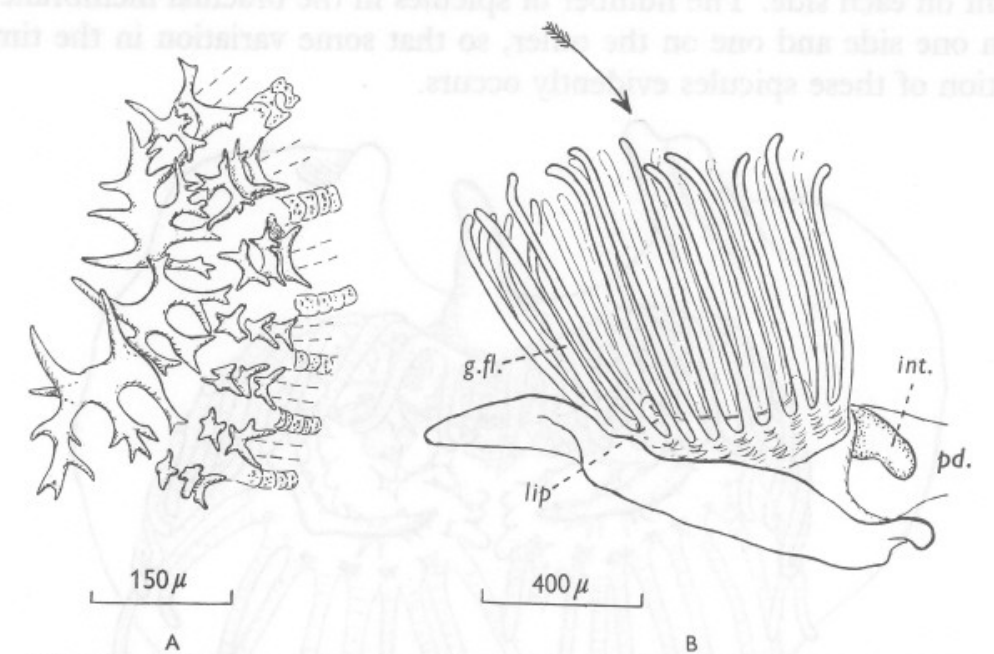

Fig. 3. Platidia davidsoni. A. Spicules of part of schizolophe of individual of shell length I. $8 \mathrm{~mm}$, width $2 . \mathrm{I} \mathrm{mm}$, viewed abfrontally, or dorsally. The inner filaments are indicated by broken lines. B. Side view of early schizolophe of an irregularly shaped individual of shell length $\mathrm{r} .8 \mathrm{~mm}$, drawn living. The arrow indicates the direction of the inhalant current. g.fl., first outer, grooved filament; int., intestine; lip, lip of the food grooves; $p d$., pedicle.

almost horizontal, divergent lamellae on the apex of the septum is apparent from its appearance in transverse sections of an individual $2 \cdot 3 \mathrm{~mm}$ long and $2.9 \mathrm{~mm}$ wide (Fig. 5). The septum was approximately $200 \mu$ long and the conjoined bases of the lamellae $80 \mu$ long antero-posteriorly, judging from the number of sections involved. The septum with the lamellae support the growing region of the lophophore and raise it above the valve floor, so that the brachial membrane slopes toward the mantle margins. At this stage the concavity formed by the upper surfaces of the lamellae is occupied by supporting substance similar to that present in the filaments. The two sections figured (Fig. 5) show the relation of the filaments to the mantle. Both small and great brachial canals are present at this stage.

The early zygolophous stage occurs between a shell length of 2.7 and $3.2 \mathrm{~mm}$. At the smaller size the inner side of the lateral arms had not yet begun to be deflected, while at the larger size this inclination had begun (Fig. 6). 

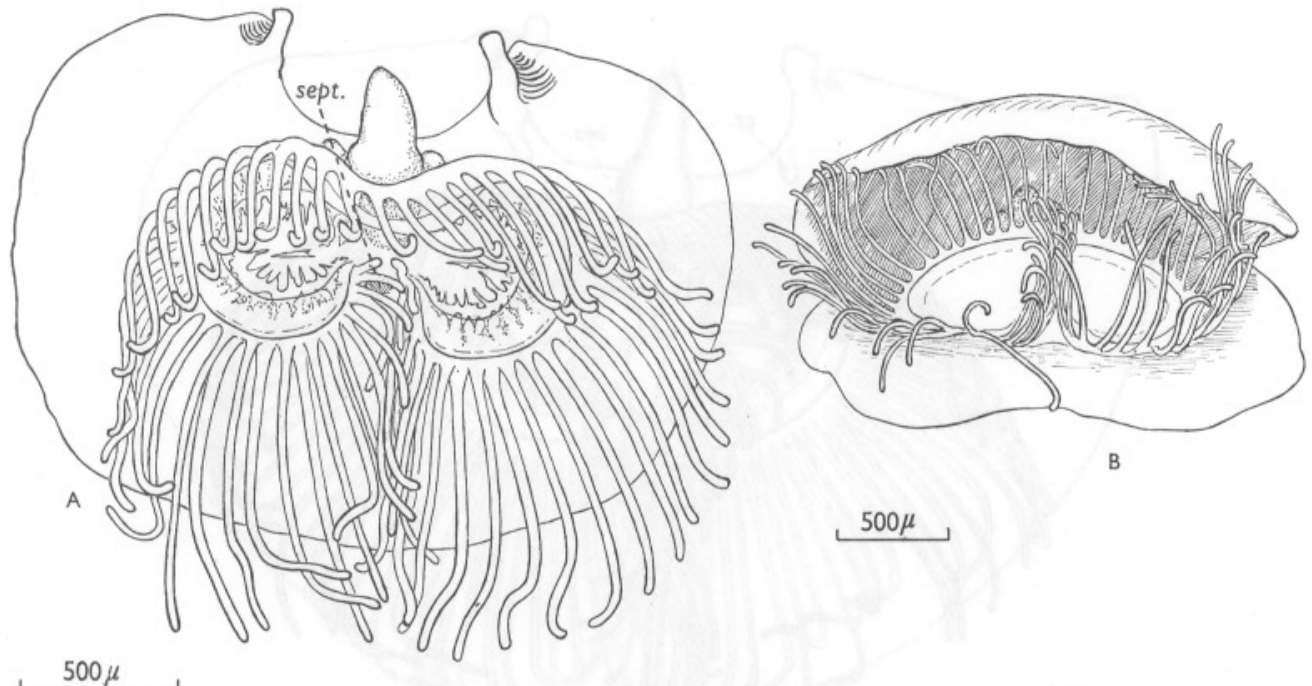

B

$500 \mu$

Fig. 4. Platidia davidsoni. A. Specimen of shell length $2.0 \mathrm{~mm}$, width $2.3 \mathrm{~mm}$ : brachial valve with schizolophe, drawn living. The filaments behind the mouth are almost erect; a septum is present. Only the larger spicules are shown. B. Specimen of shell length $2 \cdot 2 \mathrm{~mm}$, width 2.3 mm: view looking down into the shell, drawn living, but narcotized.
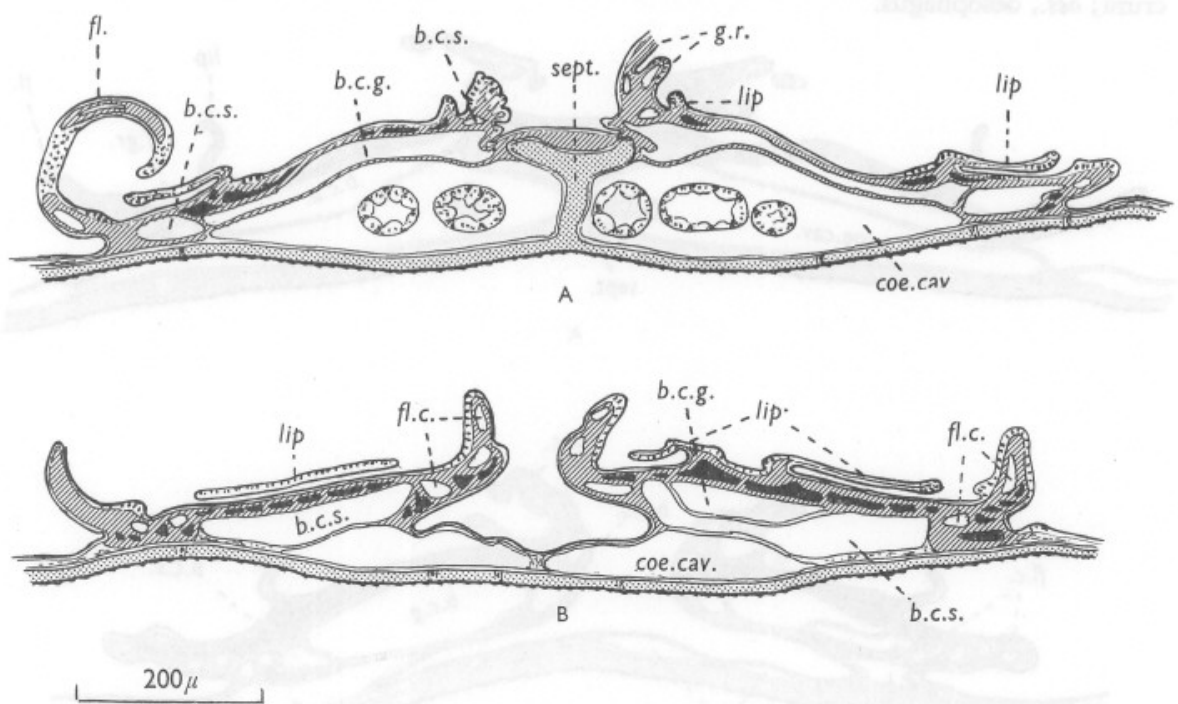

Fig. 5. Platidia davidsoni, of shell length $2 \cdot 3 \mathrm{~mm}$, width $2.9 \mathrm{~mm}$. Transverse sections through the brachial valve with schizolophe: (A) through the septum (sept.) with its divergent lamellae, and the twin growing regions of the lophophore; (B) through the anterior region of the lophophore, slightly oblique. On the right through the anterior recurvature of the small brachial canal; on the left slightly more anterior, so that the great brachial canal is absent. b.c.g., great and b.c.s., small brachial canals; coe.cav. coelomic cavity; fl., filament; fl.c., filamentar canal; g.r., growing region of right side; lip, lip of food groove. Spaces formerly occupied by spicules shown black; supporting substance shown hatched. 


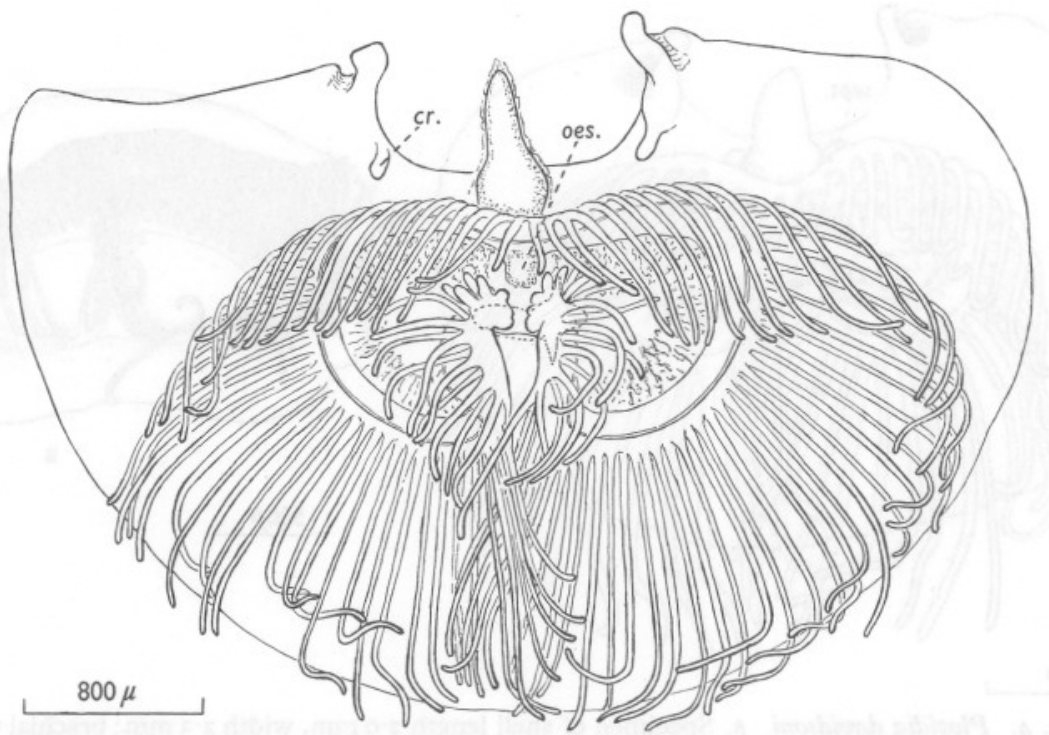

Fig. 6. Platidia davidsoni, of shell length $3.2 \mathrm{~mm}$, width $4.6 \mathrm{~mm}$. Brachial valve with zygolophe; the inner sides of the lateral arms have begun to turn outwards. Drawn living: brachial support, indicated by broken lines, added after clearing in cedar wood oil. cr., crura; oes., oesophagus.
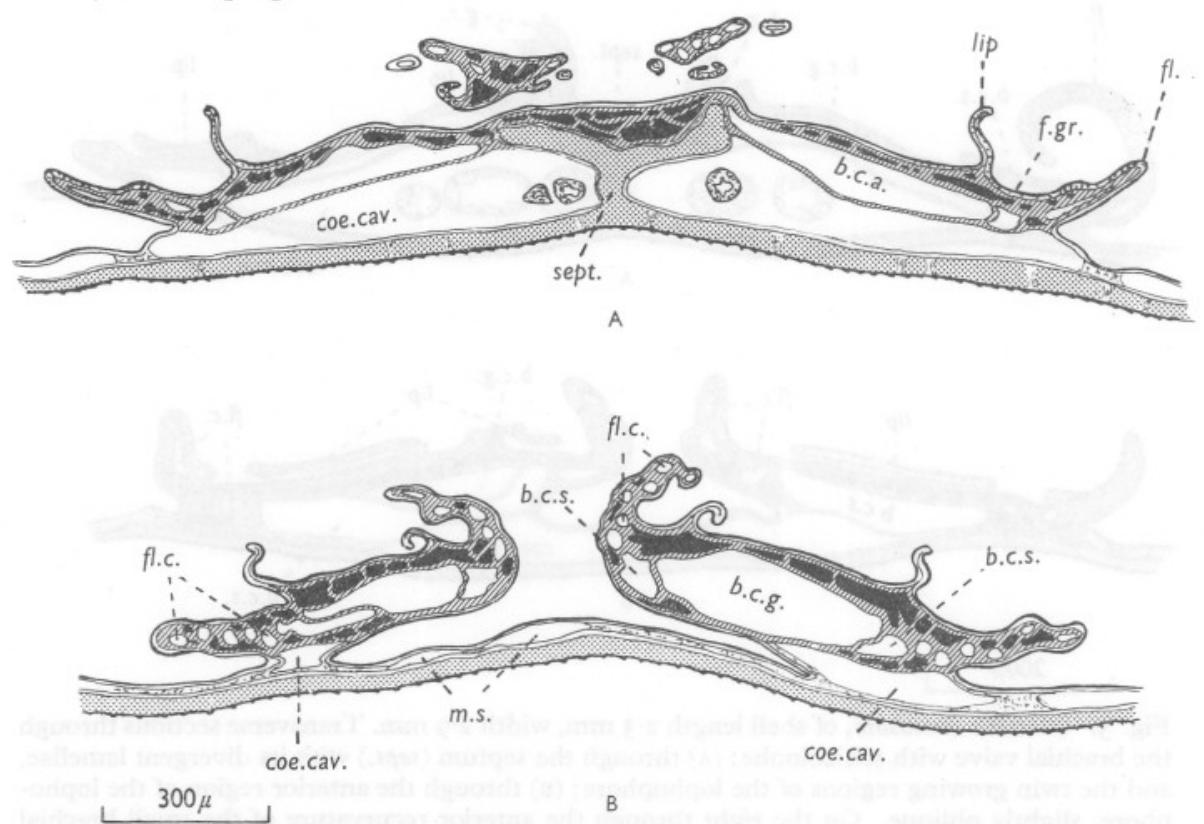

Fig. 7. Platidia davidsoni, of shell length $3.1 \mathrm{~mm}$, width $4.1 \mathrm{~mm}$. Transverse sections through the brachial valve and early zygolophe of a slightly later stage than shown in Fig. 6: (A) through the septum (sept.) and its divergent lamellae, (B) near the anterior end of the lophophore. The two lateral arms face ventrally, but slope slightly toward the mantle margins. The lateral arms are beginning to separate from the mantle anteriorly. f.gr., food groove; m.s., mantle sinus; other lettering as in Fig. 5 . 
A specimen $3.1 \mathrm{~mm}$ long and $4.1 \mathrm{~mm}$ wide was sectioned: the sections illustrated (Fig. 7) show the almost horizontal lamellae at the crest of the septum. The lophophore is being gradually raised above the valve floor, not only by the septum and its lamellae, but also by the lateral extension and increase in size of the coelomic cavity (Fig. 7A). More anterior to the section figured (Fig. 7B) the lophophore is free from the valve floor for a very short distance. At this size crura have begun to develop (Fig. 6). The brachial

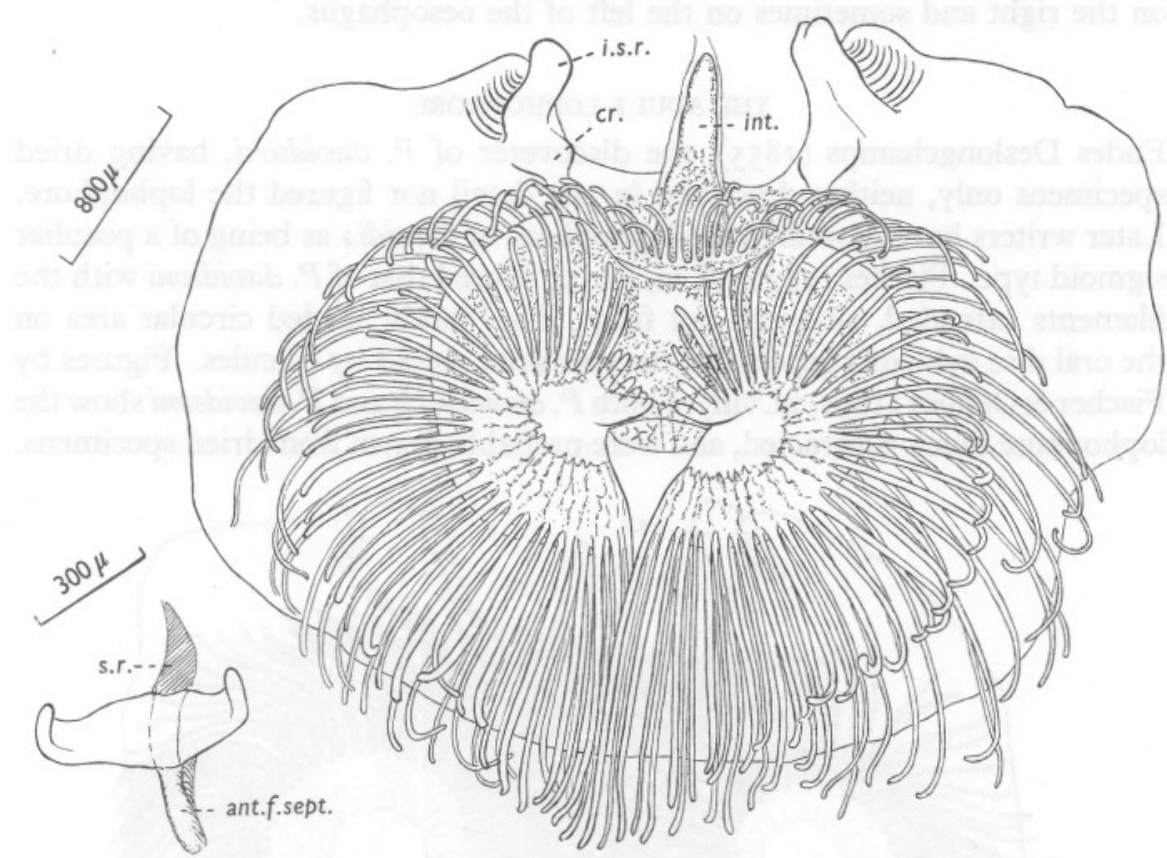

Fig. 8. Platidia davidsoni, of shell length $3.7 \mathrm{~mm}$, width $4.4 \mathrm{~mm}$. Brachial valve with late zygolophe, drawn living. Brachial support, indicated by dotted lines, added after clearing in cedar wood oil. Inset septum and divergent lamellae enlarged. ant.f.sept., anterior face of septum; cr., crura; int., intestine; i.s.r., inner socket ridge; s.r., low septal ridge.

support of an individual of greater length $(3.5 \mathrm{~mm})$, but lesser width $(3.2 \mathrm{~mm})$ is shown in Fig. I2 A, B: the septal pillar is continued posteriorly as a low ridge almost to the edge of the foramen. The posterior prolongation of the septal pillar is variable in development, for in the larger shell to be described it extended only a short distance (Fig. 8).

The late zygolophous stage occurred in an individual $3.7 \mathrm{~mm}$ long and $4.4 \mathrm{~mm}$ wide (Fig. 8). It appears to be of the normal type, except that the reflected portion of the lateral arms does not reach as far posteriorly as in most genera with plectolophes in the adult. The septum still bears what appear to be broad divergent lamellae, and these are produced on their outer ends into small ventrally curved processes (Fig. 8 , inset). Possibly the latter are 
rudiments of a transverse band, or it may be that the lamellae are undergoing transformation into the curved prongs or short ascending branches of the adult. The divergent lamellae resemble those in immature Kraussina rubra (Elliott, 1949) and in the adult Pumilus antiquatus (Atkins, 1958), but are set at a much wider angle to each other, being almost horizontal, and are borne on a high septal pillar. Crura are still short at this size.

It may be noted that the low posterior end of the septum sometimes passes on the right and sometimes on the left of the oesophagus.

\section{THE ADULT LOPHOPHORE}

Eudes Deslongchamps (1855), the discoverer of P. davidsoni, having dried specimens only, neither described in any detail nor figured the lophophore. Later writers have described the lophophore of Platidia as being of a peculiar sigmoid type. Fischer (1872, pl. vi, fig. 5) figured that of $P$. davidsoni with the filaments extended, although not fully. The darkly shaded circular area on the oral disc evidently represents the part not covered by spicules. Figures by Fischer \& Oehlert (189I, pl. viii) of both $P$. anomioides and $P$. davidsoni show the lophophore much contracted, and were probably drawn from dried specimens.



Fig. 9. Platidia davidsoni, of shell length $6.2 \mathrm{~mm}$, width $7.0 \mathrm{~mm}$. Brachial valve with fully adult plectolophe, drawn living. The spiral arm consists of one short coil. The brachial support added after clearing in cedar wood oil, but not clearly indicated. cr., crura; int., intestine; i.s.r., inner socket ridge. 
The adult lophophore of $P$. davidsoni as seen in the living animal is a somewhat modified plectolophe with a short spiral arm of little more than one coil (Fig. 9). This arm is held well away from the brachial valve by the septal pillar and the body (Figs. IO, II). In the normally feeding animal the appearance is of a broad plectolophous lophophore.

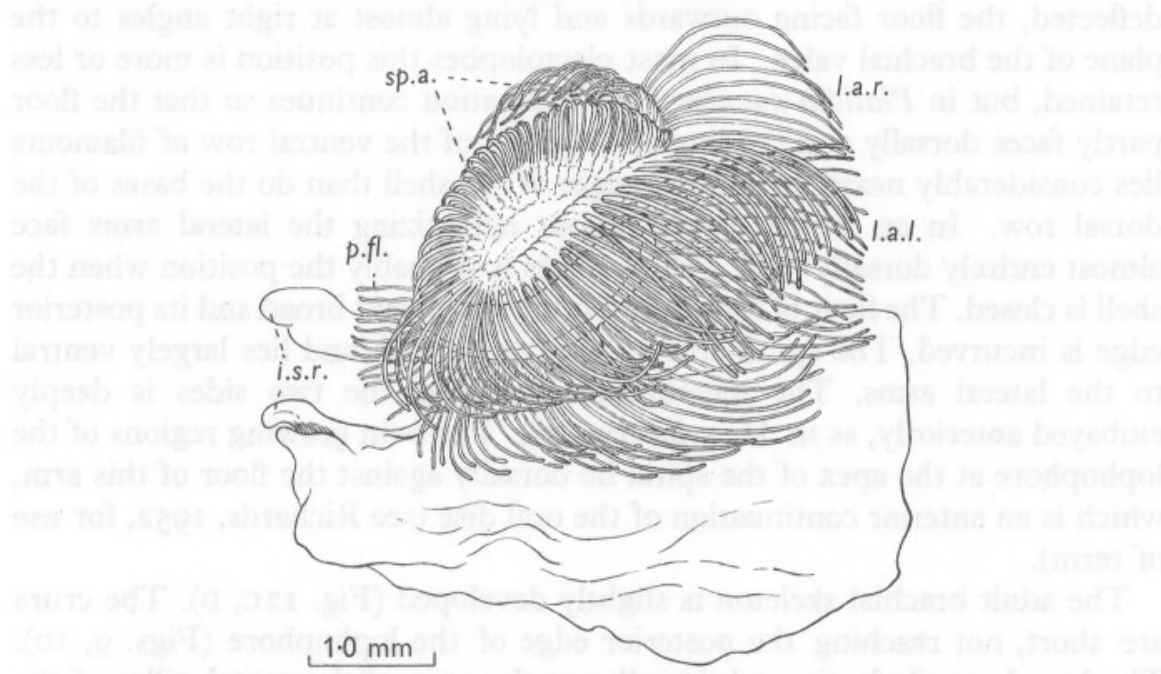

Fig. 10. Platidia davidsoni, of shell length $5.5 \mathrm{~mm}$, width $7.0 \mathrm{~mm}$; shell irregular. Side view of plectolophe, drawn after narcotizing, fixing and clearing in cedar wood oil. i.s.r., inner socket ridge; l.a.l., left and l.a.r., right lateral arm; p.fl., filaments behind mouth; sp.a., spiral arm.

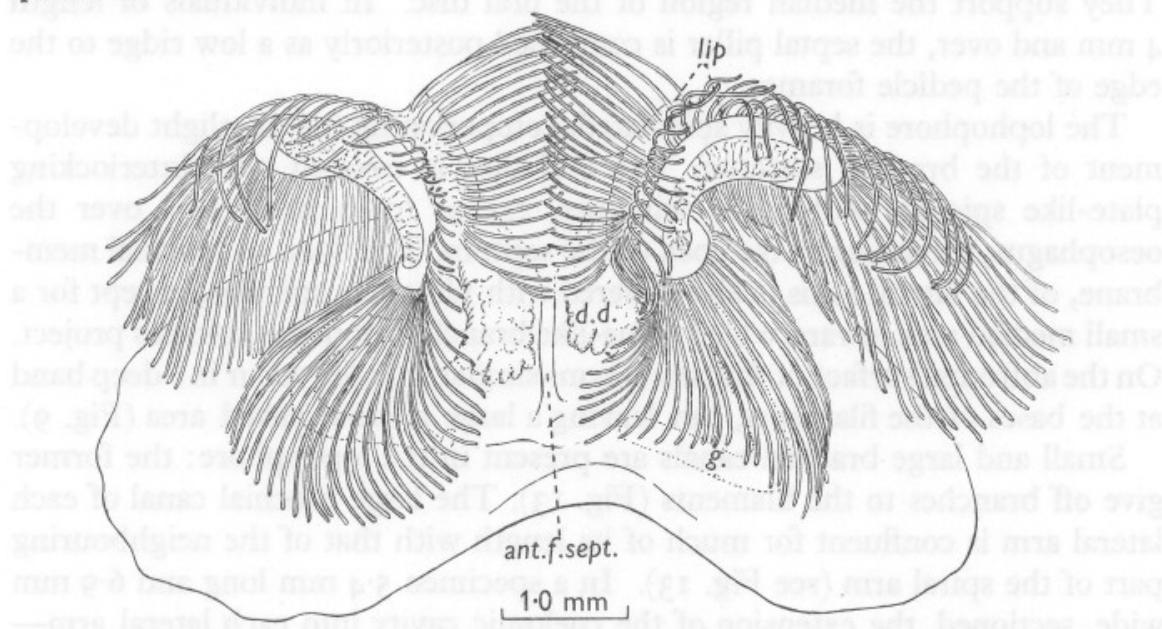

Fig. II. Platidia davidsoni. Anterior view of brachial valve and plectolophe, the ventral side only of the spiral arm shown. Same individual as in Fig. 10, but drawn living. Shell irregular with artificial sulcus caused by the surface of attachment. ant.f.sept., anterior face of septum; d.d., digestive diverticulum; g., gonad; lip, lip of food groove. 
In the schizolophous stage, as Morse (I87I, p. 420-I) noted in Terebratulina septentrionalis, and as probably in this stage in all brachiopods, the brachial membrane, or floor of the lateral arms, faces ventrally, and is almost parallel with the floor of the brachial valve, although raised to a varying degree medianly. As the zygolophous stage approaches, the lateral arms become deflected, the floor facing outwards and lying almost at right angles to the plane of the brachial valve. In most plectolophes this position is more or less retained, but in Platidia davidsoni the inclination continues so that the floor partly faces dorsally and the line of the bases of the ventral row of filaments lies considerably nearer the lateral edges of the shell than do the bases of the dorsal row. In an animal fixed without narcotizing the lateral arms face almost entirely dorsally (Fig. I3 E) and this is probably the position when the shell is closed. The floor of each lateral arm is short and broad and its posterior edge is incurved. The spiral arm is short and broad, and lies largely ventral to the lateral arms. The membrane connecting the two sides is deeply embayed anteriorly, as in Megerlia truncata. The twin growing regions of the lophophore at the apex of the spiral lie dorsally against the floor of this arm, which is an anterior continuation of the oral disc (see Richards, 1952, for use of term).

The adult brachial skeleton is slightly developed (Fig. I2C, D). The crura are short, not reaching the posterior edge of the lophophore (Figs. 9, 10). The broad, nearly horizontal, lamellae at the apex of the septal pillar of the young stages of the lophophore have changed into the prongs or short ascending branches of the adult and curve around the sides of the oesophagus. They support the median region of the oral disc. In individuals of length $4 \mathrm{~mm}$ and over, the septal pillar is continued posteriorly as a low ridge to the edge of the pedicle foramen.

The lophophore is heavily spiculated, compensating for the slight development of the brachial skeleton. The oral disc is covered with interlocking plate-like spicules with some windows, except for a small area over the oesophagus, extending to the apex of the septum. The floor, or brachial membrane, of the lateral arms is also covered with plate-like spicules, except for a small median area toward which spine-like branches from the spicules project. On the abfrontal surface of the lateral arms similar spicules occur in a deep band at the bases of the filaments, but leaving a large median naked area (Fig. 9).

Small and large brachial canals are present in the lophophore: the former give off branches to the filaments (Fig. 13). The large brachial canal of each lateral arm is confluent for much of its length with that of the neighbouring part of the spiral arm (see Fig. I3). In a specimen $5.4 \mathrm{~mm}$ long and $6.9 \mathrm{~mm}$ wide, sectioned, the extension of the coelomic cavity into each lateral armknown as the brachial pouch-was exceedingly short (Fig. I3 C).

A 'blood' vessel is present in the usual position within the small brachial canal and a branch is given off to each filament. 
The development of muscle fibres in the walls of the canals is slight.

The principal (n.p.) and external (n.ext.) nerves of the lophophores are clearly discernible, while the secondary nerve (n.sec.) is difficult to distinguish. At the magnification of the section drawn (Fig. I3F) no more than the position of the nerves can be indicated.

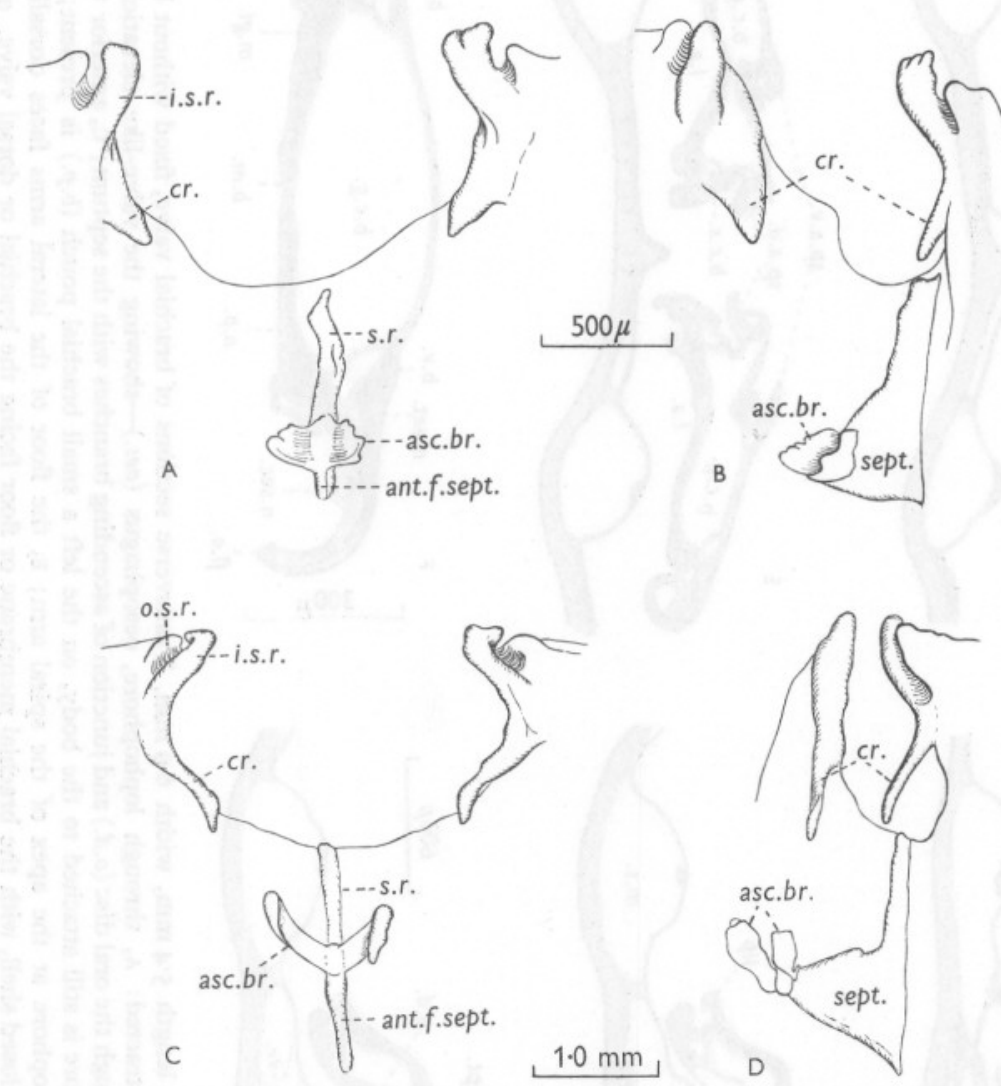

Fig. 12. Platidia davidsoni. Brachial support of: $\mathrm{A}$ and $\mathrm{B}$, individual of shell length $3.5 \mathrm{~mm}$, width $3.2 \mathrm{~mm}$; C and $\mathrm{D}$, individual of shell length $6.6 \mathrm{~mm}$, width $8.4 \mathrm{~mm}$. A and $\mathrm{C}$ ventra views; $\mathrm{B}$ and $\mathrm{D}$ lateral views. ant.f.sept., anterior face of septal pillar; asc.br., ascending branch; cr., crura; i.s.r., inner, and o.s.r., outer socket ridges; s.r., septal ridge; sept., septum.

The distribution of the mucous gland cells on the lophophore is similar to that in other plectolophes. The abfrontal band below the filaments-in the exhalant chamber-is narrow, but the cells are deep. A narrow band of deep gland cells is present on the brachial membrane at the base of the lip of the food groove (Fig. I3F). Scattered mucous cells occur in the walls, including the lip, of the food groove. 

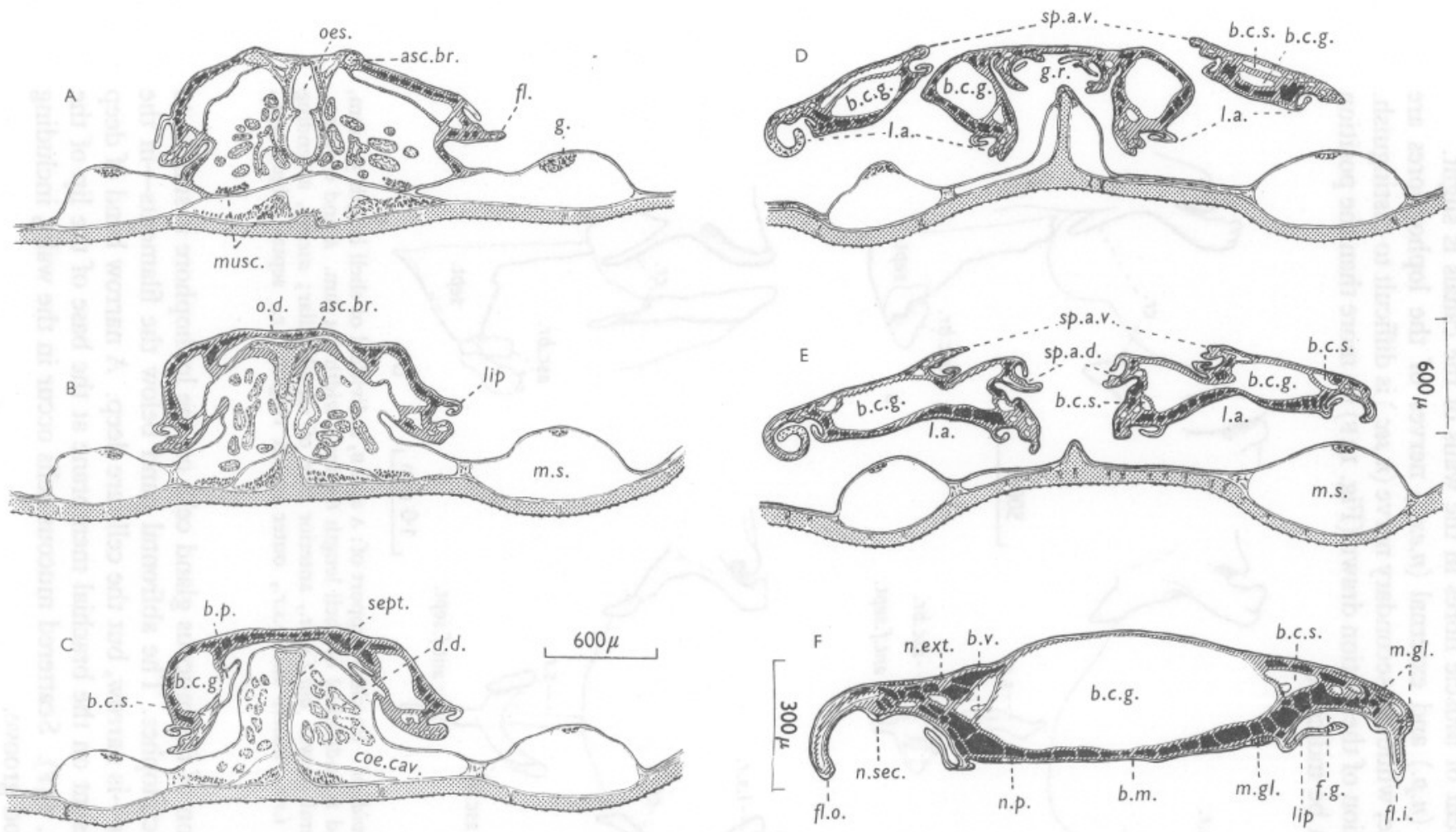

Fig. 13. Platidia davidsoni, of shell length $5.4 \mathrm{~mm}$, width $6.9 \mathrm{~mm}$. Transverse sections of brachial valve, fixed without being narcotized and therefore with plectolophe contracted: A, through lophophore, oesophagus (oes.)-showing the valve-like elevation of the walland the ascending branches; $\mathrm{B}$, through the oral disc (o.d.) and junction of ascending branches with the septum; $\mathrm{c}$, anterior to the ascending branches - on the right the lophophore is still attached to the body, on the left a small brachial pouch (b.p.) is present; D, through the growing regions (g.r.) of the lophophore at the apex of the spiral arm; E, the floor of the lateral arms faces dorsally; F, transverse section of lateral arm in position in closed shell, with the brachial membrane or floor facing the brachial or dorsal valve. asc.br., ascending branches; b.c.g., great, and b.c.s., small brachial canals; b.m., brachial membrane; b.v., 'blood' vessel; coe.cav., coelomic cavity; d.d., digestive diverticula; fl., filament; fli., inner and fl.o., outer filaments and bases; f.g., food groove; g., gonad; l.a., lateral arm; lip, lip of food groove; m.gl., mucous gland cells; m.s., mantle sinus; musc., muscle; n.ext., external; n.p., principal; and n.sec., secondary nerves; sept., septum; sp.a.d., dorsal and sp.a.v., ventral side of spiral arm. Spaces formerly occupied by spicules shown black: supporting substances shown hatched. 
The filaments are arranged in a double alternating series of inner filaments, with ridged frontal surfaces, and outer filaments with grooved frontal surfaces, but behind the mouth some sixteen or seventeen pairs are in single series and of the ridged type. Spicules are present in both types of filament. They are broad transverse bands, granulated and somewhat irregular in outline, present abfrontally within the tube of supporting substance and curving around the sides of the filaments (Figs. I4, I 5). The supporting substance in brachiopods was described as semi-cartilagenous by Hancock (1858), but according to Prenant (1928) working on Terebratulina retusa (=caput-serpentis) it is more nearly like collagen: he preferred to call it simply 'substance de soutien'.



Fig. 14. Platidia davidsoni. Spicules in two adjacent filaments at the same distance from the food groove, viewed from the frontal surface. A, an inner filament, with ridged frontal surface; $\mathrm{B}$, an outer filament, with grooved frontal surface. t.s., tube of supporting substance.

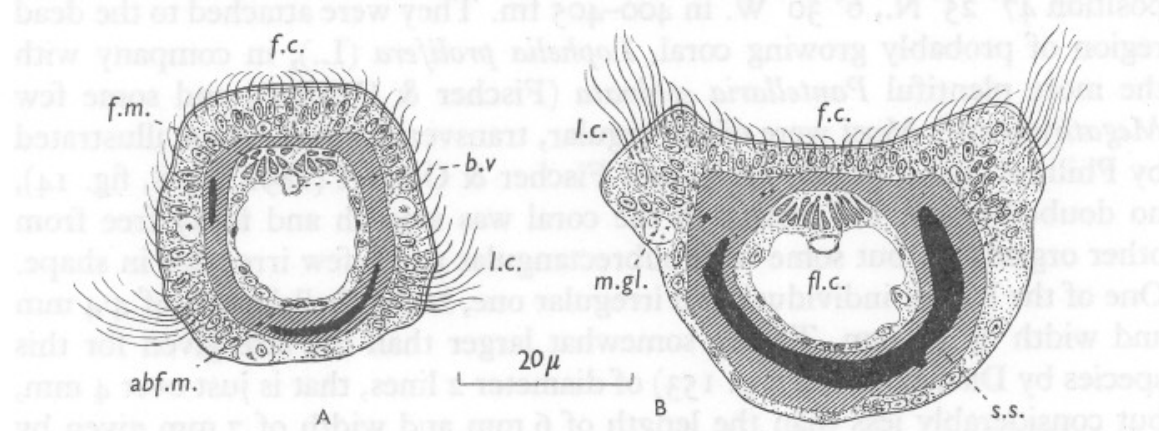

Fig. 15. Platidia davidsoni. Transverse sections of A, inner filament, with ridged frontal surface; $\mathbf{B}$, outer filament, with grooved frontal surface. abf.m., abfrontal muscles; b.v., 'blood' vessel; f.c., frontal cilia; fl.c., filamentar canal; f.m., frontal group of muscles; l.c., lateral cilia; m.gl., mucous gland cell; s.s., supporting substance. Spaces formerly occupied by spicules shown black. Frontal cilia not shown at their full length, as they beat along the filament. 
Longitudinal muscle fibres are present in the walls of the filamentar canal, especially well developed in a striated frontal group and to a lesser extent abfrontally (Fig. I5); the latter appear to be smooth.

The structure of the lophophore of Platidia is peculiarly adapted to the shallow mantle cavity of the closed shell. In separating and closing the valves of a detached living animal it is possible to see something of the normal movements of the lophophore. As the valves are closed the anterior ends of the side arms approach each other in the mid-line and the whole lophophore appears to be flattened by the approximation of the valves. As the valves are separated the lophophore is raised, although under these conditions the filaments remain tightly coiled. It would seem that it is so constructed that it can be flattened by the approximation of the valves, and fitted into the small dorso-ventral space available: the largely spicular support of the lophophore, and the floor of the lateral arms being approximately parallel with the valve floor making this possible. When the valves are gaping widely, as naturally when feeding, there is ample space for the spiral arm to expand.

When the valves are closed the prongs at the apex of the septal pillar almost touch the floor of the ventral valve, as can be observed through the foramen of an empty shell. This close proximity of the median region of the brachial support to the ventral valve in the closed shell seems not unusual in brachiopods. In young Macandrevia cranium the apex of the hood almost touches the pedicle valve when the shell is closed.

\section{PLATIDIA ANOMIOIDES (PHILIPPI)}

On I3 May 1958 , over sixty $P$. anomioides from $I \cdot I$ to $4.6 \mathrm{~mm}$ long were dredged by R.V. 'Sarsia' somewhat to the south-east of La Chapelle Bank in position $47^{\circ} 25^{\prime} \mathrm{N}$., $6^{\circ} 30^{\prime} \mathrm{W}$. in $400-405 \mathrm{fm}$. They were attached to the dead region of probably growing coral, Lophelia prolifera (L.), in company with the more plentiful Pantellaria echinata (Fischer \& Oehlert), and some few Megathyris sp. ${ }^{1}$ Most were of the regular, transversely oval, shape illustrated by Philippi (I844, pl. I8, fig. 9) and Fischer \& Oehlert (I891, pl. 8, fig. I4), no doubt because the surface of the coral was smooth and fairly free from other organisms, but some were subrectangular and a few irregular in shape. One of the largest individuals, an irregular one, had a shell length of $4.4 \mathrm{~mm}$ and width of $5.0 \mathrm{~mm}$. This is somewhat larger than the size given for this species by Davidson (1887, p. 153) of diameter 2 lines, that is just over $4 \mathrm{~mm}$, but considerably less than the length of $6 \mathrm{~mm}$ and width of $7 \mathrm{~mm}$ given by Fischer \& Oehlert (I89I, p. 95). Massy (1925) records a maximum size of ca. $5 \times 6 \mathrm{~mm}$ of specimens taken on Lophohelia (=Lophelia) off the south-west of Ireland. The young are occasionally rather longer than broad, but with

\footnotetext{
1 Bivalves on the coral were few.
} 
growth tend to become as wide or wider than long. The mantle margin is furnished with fairly short setae, as in $P$. davidsoni.

The numbers of $P$. anomioides obtained has allowed of the working out of the growth stages of the lophophore, and in particular of the brachial support, which is considerably further developed than in P. davidsoni.

\section{THE GROWTH STAGES OF THE LOPHOPHORE AND ITS SUPPORT}

The lophophore of $P$. anomioides unfortunately did not expand well after separation of the valves; stovaine failed to give good results and magnesium chloride did not always act well.

The lophophore passes through the growth stages described for P. davidsoni. The filaments appear to be generally longer than in that species-compare, for instance, Figs. 3B and 16 and Figs. 9 and 2I-and a greater number are in single series behind the mouth, some 25 or 26 pairs as compared with 16 or $\mathrm{I} 7$ pairs in $P$. davidsoni.

The lophophore is trocholophous (Fig. I6) up to a shell length of about $\mathrm{I} .6 \mathrm{~mm}$ : it then becomes slightly indented in the mid-line anteriorly. A minute triangular septum and short crura are present. The individual figured (Fig. I7), of shell length $\mathrm{I} \cdot 8 \mathrm{~mm}$ and width $\mathrm{I} \cdot 9 \mathrm{~mm}$, had the lophophore poorly expanded, but clearly shows the relation of the septum to the anterior median invagination. All the filaments were in a single row and were spiculated: spicules were also present in a wide band at their bases. Fig. I 8 shows the characteristic arrangement of a large spicule on each side of the septum, the two converging anteriorly. At a diameter of some $2 \mathrm{~mm}$ the crura were longer than shown in Fig. 17, and the triangular septum somewhat higher, but as yet not bifurcated (Fig. 23A). Minute projections were present at its apex at a shell length of $2.3 \mathrm{~mm}$ and width $2.5 \mathrm{~mm}$ (Fig. 20A).

The late schizolophous stage was found at a diameter of $2.5 \mathrm{~mm}$ : the inner side of the side arms or lobes had begun to turn outwards, this stage corresponding to that figured for $P$. davidsoni at a length of $3.2 \mathrm{~mm}$ (see Fig. 6). The crura were short and reached to just behind the lophophore; crural processes were absent. The apex of the septum was forked; anterior ends of the descending branches if present must have been short as they were not distinguishable in the uncleared animal. It would appear that in this individual the lophophore was somewhat retarded in development as the zygolophous stage occurred in three individuals of length $2.4 \mathrm{~mm}$, width $2.8 \mathrm{~mm}$ (Fig. 19); length $2.6 \mathrm{~mm}$, width $2.9 \mathrm{~mm}$; and length $2.6 \mathrm{~mm}$, width $2.7 \mathrm{~mm}$. In the first two of these the twin-growing regions of the lophophore were close together, in the last they were separated. In all three crural processes were present, although short: the posterior ends of the descending branches were either short or not yet formed; the anterior ends were present and longest in the third specimen. The ascending branches at the apex of the septum were best developed in the second specimen. At a length and width of of $3.3 \mathrm{~mm}$ 


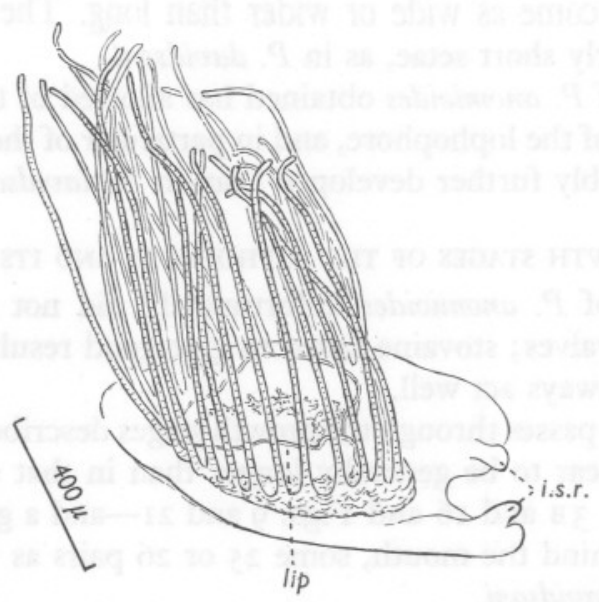

Fig. I6. Platidia anomioides, shell length $\mathrm{I} \cdot 2 \mathrm{~mm}$, width $\mathrm{I} \cdot 3 \mathrm{~mm}$. Side view of brachial valve with trocholophe, drawn narcotized. Spicules indicated, except in filaments of the far side. i.s.r., inner socket ridge; lip, lip of food groove.

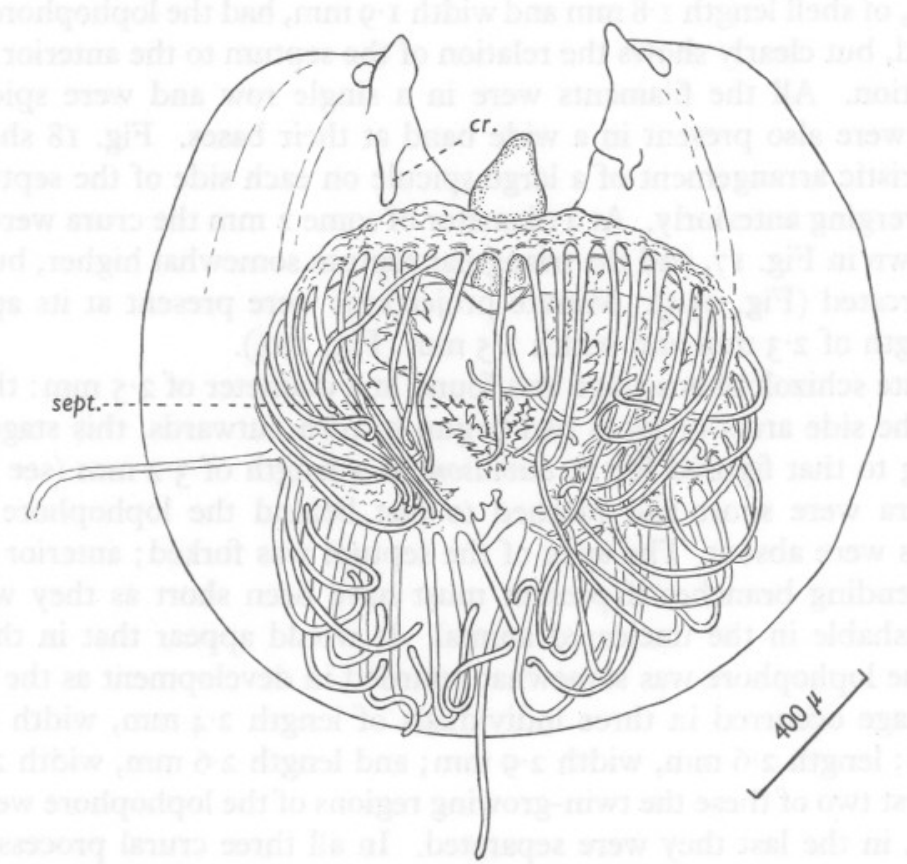

Fig. 17. Platidia anomioides, shell length $\mathrm{I} \cdot 8 \mathrm{~mm}$, width $\mathrm{r} \cdot 9 \mathrm{~mm}$. Brachial valve with early schizolophe, drawn unsuccessfully narcotized. It shows the relation of the septum (sept.) to the anterior median invagination of the lophophore. cr., crura, sept., septum. 


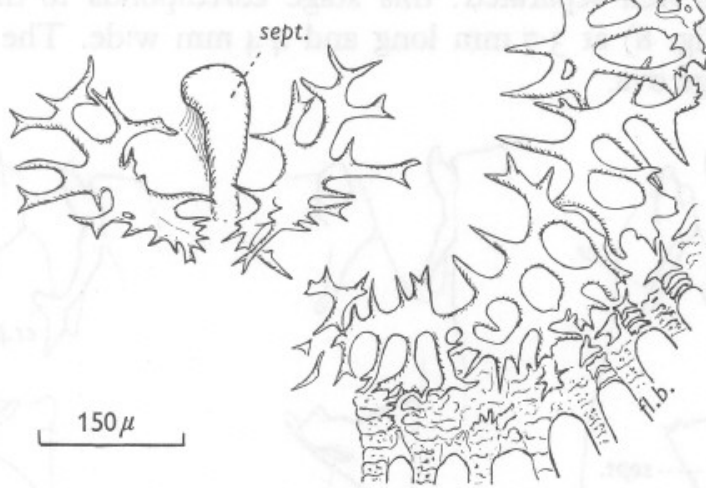

Fig. 18. Platidia anomioides, of length $\mathrm{I} \cdot 9 \mathrm{~mm}$, width $2 \cdot 2 \mathrm{~mm}$. Spicules of part of schizolophe viewed ventrally. The large spicules, one on each side of the septum (sept.) are to be noted. fl.b., bases of filaments in single series at this stage.

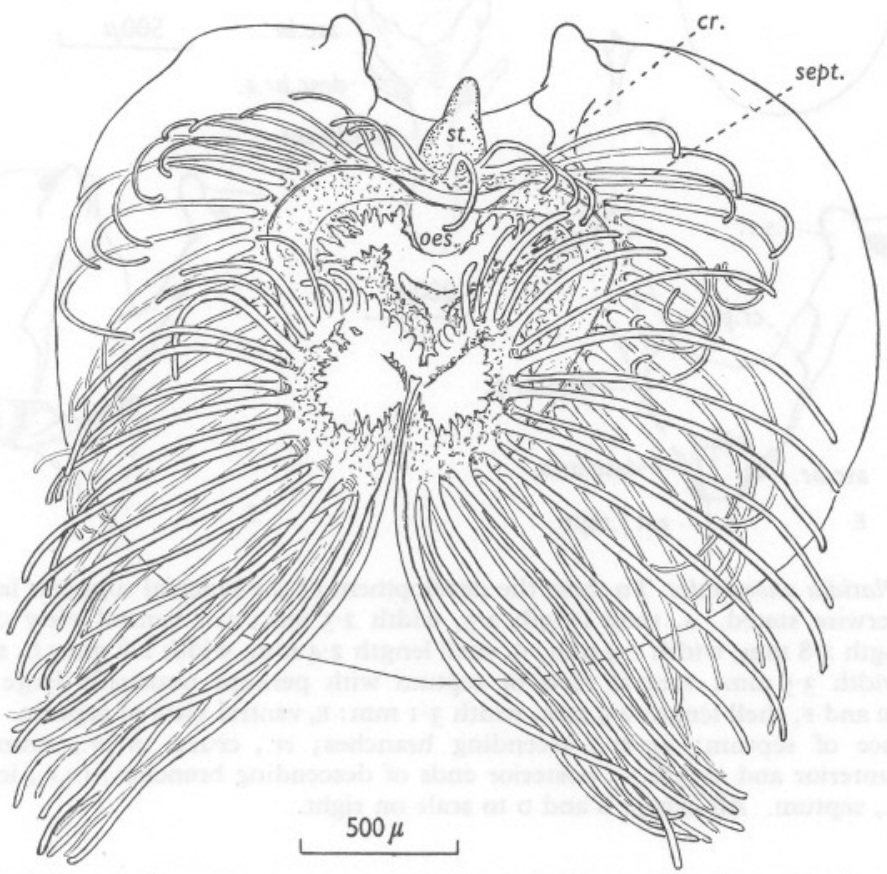

Fig. 19. Platidia anomioides, of length $2.4 \mathrm{~mm}$, width $2.8 \mathrm{~mm}$. Brachial valve with zygolophe, the twin growing regions close together: drawn narcotized. cr., crura; oes, oesophagus; sept., septum, with ascending branches; st., stomach. 
the lophophore was late zygolophous or very early plectolophous with the growing regions well separated: this stage corresponds to that figured for $P$. davidsoni (Fig. 8) at $3.7 \mathrm{~mm}$ long and $4.4 \mathrm{~mm}$ wide. The animal was a female with large ova.

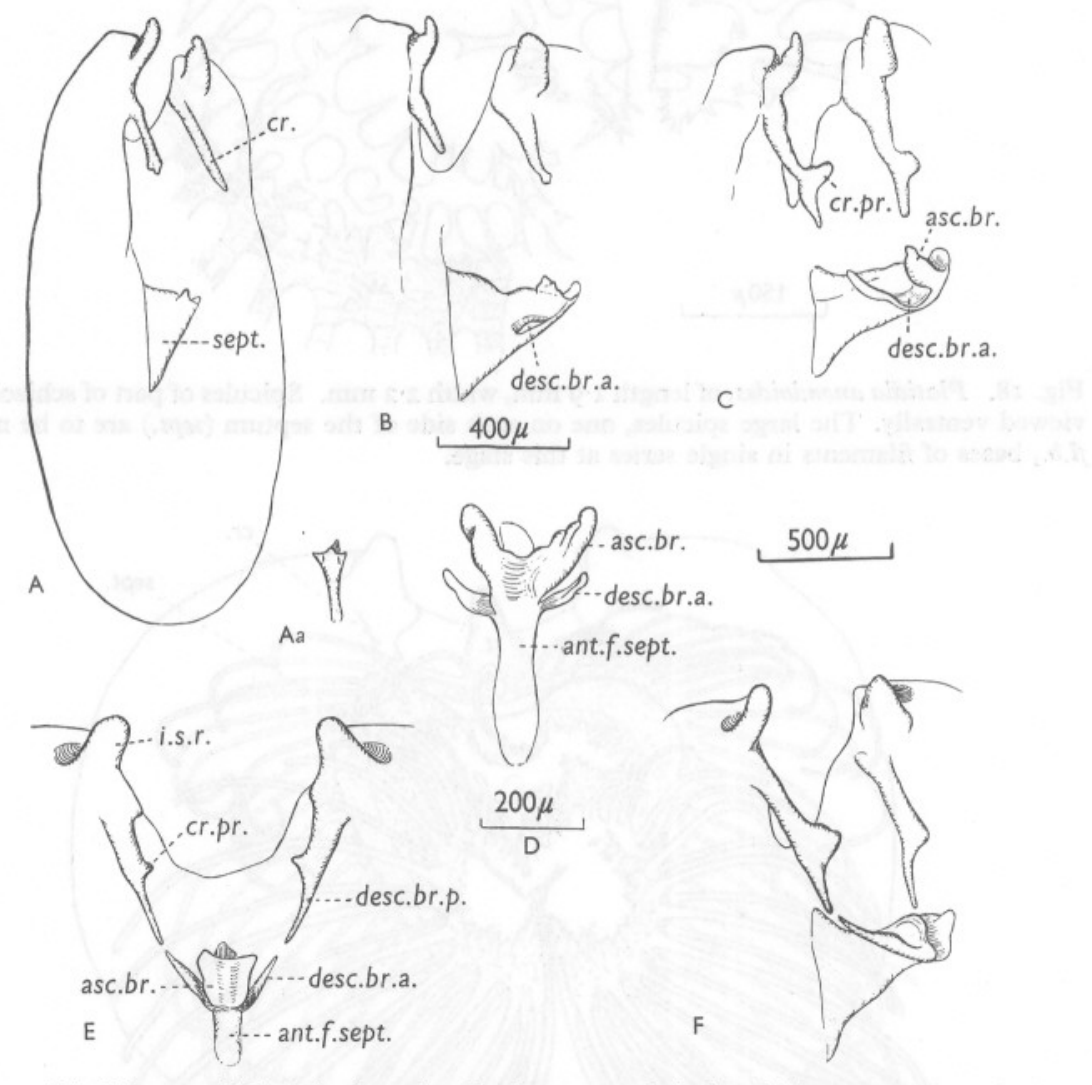

Fig. 20. Platidia anomioides. To show the development of the brachial support: lateral views unless otherwise stated. A, shell length 2.3 , width $2.5 \mathrm{~mm}$; Aa, ventral view of septum; B, shell length $2.8 \mathrm{~mm}$, width $2.9 \mathrm{~mm}$; C, shell length $2.4 \mathrm{~mm}$, width $2.8 \mathrm{~mm}$; D, shell length $2.9 \mathrm{~mm}$, width $3.5 \mathrm{~mm}$; ventral view of septum with perhaps unusually large ascending branches; $\mathrm{E}$ and $\mathrm{F}$, shell length $2.9 \mathrm{~mm}$, width $3 . \mathrm{I} \mathrm{mm:} \mathrm{E,} \mathrm{ventral} \mathrm{view} \mathrm{of} \mathrm{septum.} \mathrm{ant.f.sept.,}$ anterior face of septum; asc.br., ascending branches; cr., crura; cr.pr., crural process, desc.br.a., anterior and desc.br.p., posterior ends of descending branches; i.s.r., inner socket ridge; sept., septum. All except B and D to scale on right.

As fine details of the brachial support are not easily discernible in valves in which the flesh is present, they will be described from those in which it had been removed. The anterior ends of the descending branches had begun to grow from the septum in an individual of shell length $2.8 \mathrm{~mm}$ and width $2.9 \mathrm{~mm}$ (Fig. 20B). The crura were short and crural processes absent. In one 




Fig. 21. Platidia anomioides, of shell length $4.6 \mathrm{~mm}$, width $4.4 \mathrm{~mm}$. Brachial valve with plectolophe, drawn living and narcotized.

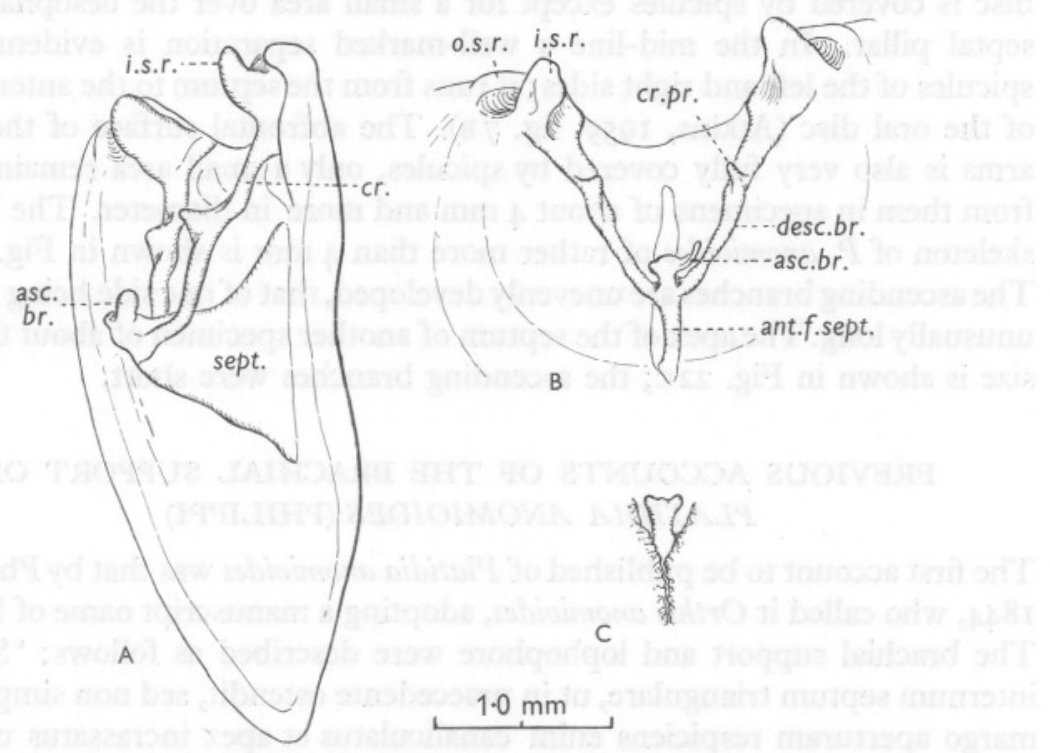

Fig. 22. Platidia anomioides, of shell length and width approximately $4 \mathrm{~mm}$. A, side view of brachial valve; $\mathrm{B}$, ventral view of brachial support, with the ascending branches unequally developed; c, ventral view of the septum of another individual of about the same size. o.s.r., outer socket ridge; other lettering as in Fig. 20. 
of smaller size, length $2.4 \mathrm{~mm}$ and width $2.8 \mathrm{~mm}$, the brachial support was more advanced in development. The anterior ends of the descending branches were longer and had moved up the septum to near the origin of the ascending branches: the posterior ends had begun to grow from the crura, on which short crural processes were present (Fig. 20C). The ascending branches at the apex of the septum are variably developed in $P$. anomioides, but are generally very short even in the adult. Fig. 20D is an anterior view of a septum with rather well-developed ascending branches of an individual of length $2.9 \mathrm{~mm}$ and width $3.5 \mathrm{~mm}$.

The anterior and posterior ends of the descending branches had almost met in a specimen of length $2.9 \mathrm{~mm}$ and width $3.1 \mathrm{~mm}$. The ascending branches were extremely short, appearing as two short lamellae on the apex of the septum (Fig. 20E, F).

The adult lophophore (Fig. 2I) is like that of $P$. davidsoni. The floor of the lateral arms, however, is perhaps even more fully dorsally facing: the lateral arms have longer filaments anteriorly and their abfrontal surfaces are more entirely covered by spicules. The spiral arm is small, of one coil only. The dorsal filaments of the lateral arms extend but a short distance beyond the edge of the brachial valve, except anteriorly where they lengthen as they become continuous with the long ventral filaments. The lophophore when expanded slants upwards at an angle of some $45^{\circ}$ with the surface of the dorsal valve, so that it is raised high above the valve anteriorly. This anterior upward tilting of the lophophore is found also in P. davidsoni (see Fig. I0). The oral disc is covered by spicules except for a small area over the oesophagus and septal pillar. In the mid-line a well-marked separation is evident of the spicules of the left and right sides; it runs from the septum to the anterior edge of the oral disc (Atkins, 1959, fig. 7B). The abfrontal surface of the lateral arms is also very fully covered by spicules, only a small area remaining free from them in specimens of about $4 \mathrm{~mm}$ and more in diameter. The brachial skeleton of $P$. anomioides of rather more than $4 \mathrm{~mm}$ is shown in Fig. 22 A, B. The ascending branches are unevenly developed, that of one side being perhaps unusually long. The apex of the septum of another specimen of about the same size is shown in Fig. 22 C; the ascending branches were short.

\section{PREVIOUS ACCOUNTS OF THE BRACHIAL SUPPORT OF PLATIDIA ANOMIOIDES (PHILIPPI)}

The first account to be published of Platidia anomioides was that by Philippi in I844, who called it Orthis anomioides, adopting a manuscript name of Scacchi. The brachial support and lophophore were described as follows: 'Sceleton internum septum triangulare, ut in praecedente ostendit, sed non simplex est; margo aperturam respiciens enim canaliculatus et apex incrassatus utrinque bicarinatus, inter carinas foveolatus est. Brachia circulos perfectos describunt, 
cirrosque externe gerunt'. No mention was made of descending branches. The length of the shell was given as $I_{\frac{3}{4}}^{\prime \prime \prime}$, and the width as $2^{\prime \prime \prime}$.

In January 1852 Costa gave the name Platidia to the genus of which $P$. anomioides was the type and only species. Davidson unaware of this, in May I852a (p. 37I) gave the name Morrisia to the genus and described 'the apophysary system consisting of two branches, originating at the base of the dental sockets, and united to a small elevated process arising from the centre of the valve'. As the type of the genus he gave $M$. seminulum. One of the accompanying figures appears to show two minute horns at the apex of the septum, although these are not mentioned in the text. The other figure shows the lophophore 'with two subspiral or sigmoid arms' and the filaments quite well extended: a spiral arm, however, is not shown. It was apparently drawn from a dried specimen (see Davidson, I887, p. I53). The above description of the lophophore and its support was repeated under the name Morrisia anomioides by Davidson (1852c) in the same year in the Proc. Zool. Soc.

In 1887 (p. I 53) Davidson's description was as follows: 'in the interior of the dorsal valve the loop is not reflected. The converging principal lamellae are found attached first to the hinge-plate, and then to a small pillar-shaped median vertical septum'. The accompanying figure (1887, pl. 21, fig. I8) shows no horns on the septum.

Fischer \& Oehlert (I89I, p. 94) described and figured the brachial support as more fully developed than in any previous account. They said: 'De la base de ces apophyses fovéales s'élèvant presque verticalement deux cruras longs et grêles, limités par deux fines pointes crurales, au delà desquelles les branches descendantes, minces et ténues, vont en convergeant rejoindre un pilier septal très élevé, auquel elles se soudent vers les trois quarts de sa hauteur. Le pilier est constitué par une lamelle triangulaire remontant jusqu'au bord de l'échancrure; cette lamelle, peu épaisse, est arquée vers l'arrière et légèrement renflée au sommet, qui se termine par deux pointes divergentes courtes et assez massives, supportant la membrane brachiale médiane'.

It is most probable from the appearance of the shell and pedicle opening that Philippi's $P$. anomioides is the same shell as now goes under that name, although his description of the brachial support, without descending branches, would apply to $P$. davidsoni. Philippi's specimen of $P$. anomioides, about $3.5 \mathrm{~mm}$ long and about $4 \mathrm{~mm}$ wide, is of a size to have the descending branches complete if they had not been broken.

THE IDENTITY OF TEREBRATULA SEMINULUM PHILIPPI 1836

Philippi in 1836 published a short account with figures (pl. vi, fig. I5) of a small shell which he called Terebratula seminulum. His description is as follows: 'Testa circa $I^{\prime \prime \prime}$ longa, totidem lata, mox exacte orbicularis, mox transversa, mox ovata, in fronte saepe emarginata, vid. fig. $b, d, e, f$, semper 
compressa, densissime punctata. Apertura incompleta, v. fig. $15 d$; deltidium non vidi. Sceleton internum simplicissimum, a lamella triangulari versus frontem declivi formatum, v. fig. $a$ ubi a latere inspectum est. Brachia versus cardinem connata seriem ciliarum simplicem, orbicularem antice interruptam exhibent v. f. $b$. Color testae albidus'.

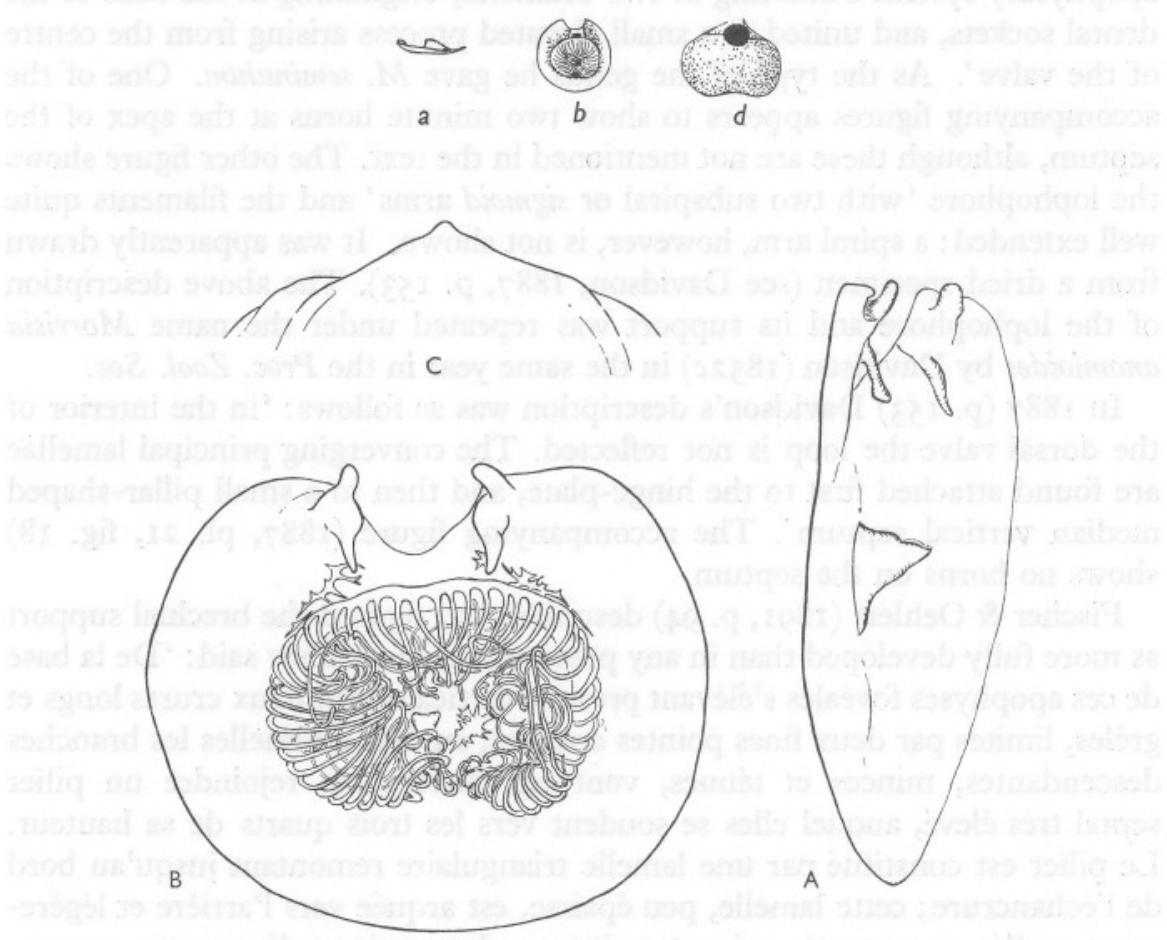

Fig. 23. A, B, C, Platidia anomioides of diameter $2 \mathrm{~mm}$ : A, side view of brachial valve; B, brachial valve with contracted schizolophe; $\mathrm{C}$, beak of shell viewed ventrally (B and $\mathrm{C}$ are of a second individual). $a, b, d$. Terebratula seminulum Philippi of diameter I line, after Philippi's fig. I5 $a, b, d$, for comparison with Platidia anomioides of the same size.

There has been argument as to whether T. seminulum is a Platidia or an Argyrotheca (=Argiope). In 1844 (p. 69) Philippi in describing Orthis neapolitana Scacchi (now Argyrotheca cordata) said 'cfr. vol. I, p. 97, t. 6, f. I5 nomine Tereb. seminuli'. This possibly accounts for Davidson's ( $1852 b$, p. 5I4) statement in corrections to his paper earlier in the same volume (1852a, pp. 36I-77) that "the name seminulum was intended by Philippi for an Argiope, although his figure may have been taken from more than one shell'. In his paper (I852a) Davidson had evidently described and figured the Platidia anomioides of Philippi under the name Morrisia seminulum Philippi, and in I92I (p. 332) Dall called it Platidia seminula, the generic name 
Platidia having been proposed for the genus by Costa in January 1852 , a few months earlier than Davidson's name of Morrisia.

Fischer \& Oehlert (I891, p. 97) considered not only that Platidia anomioides and Terebratula seminulum were distinct, but that the latter probably belonged to a different generic group, perhaps to Cistella (=Argyrotheca): their opinion was apparently based on the form of the lophophore. Thomson (I927, p. 218) said that Platidia anomioides 'has been confused by Davidson and Dall (I92I) with Terebratula seminulum Philippi, 1836 , a species of similar external form referable to the genus Amphithyris'. Thomson (p. 216) separated Terebratula seminulum from Platidia anomioides because 'of the distinct character of the lophophore'. He had apparently temporarily overlooked the fact that as far as was known all the more highly organized lophophores pass through a schizolophous stage-the type of lophophore depicted by Philippi for Terebratula seminulum - and there was no reason to assume that Platidia anomioides was an exception, or that Terebratula seminulum seen by Philippi was necessarily in an adult state at a diameter of $\mathrm{I}$ line, that is approximately $2 \mathrm{~mm}$.

Jeffreys (I878, p. 4II) mentioned that according to Seguenza the young of Platidia anomioides is the Terebratula seminulum of Philippi, and this is probably what it is. Platidia anomioides at a shell length of about $2 \mathrm{~mm}$ closely resembles in shell form, triangular septum (Fig. 23A) and schizolophous lophophore (shown contracted in Fig. 23B) the figures by Philippi (1836, pl. 6 , fig. $15 a, b, d)$, reproduced in Fig. $23 a, b, d$, of Terebratula seminulum from Sicily of the same size. He clearly shows the amphithyrid foramen, not present in the genus Argyrotheca. The identity of the shell he figured in pl. 6, fig. I $5 e, f, g$, is uncertain: it appears too elongated for even a young Platidia.

Unless Philippi's specimens of Terebratula seminulum are in existence and can be examined to determine without any doubt that they are the young of Platidia anomioides, then it seems best to leave that name undisturbed.

\section{FURTHER REMARKS ON LOPHOPHORES}

The brachial support is in a more advanced state in adult Platidia anomioides than in adult $P$. davidsoni, in that the descending branches are present and complete in the former and absent in the latter. But on the other hand the ascending branches are larger in $P$. davidsoni than in $P$. anomioides. In $P$. anomioides the descending branches, although complete, reach only to the centre of the oral disc, leaving the lateral arms unsupported except by spicules. This arrangement no doubt allows of the packing away of the lophophore in the constricted space available when the shell is closed.

The ascending branches or divergent lamellae of immature $P$. davidsoni are reminiscent of those of immature Kraussina rubra (Elliott, 1949) and of adult Pumilus antiquatus (Atkins, 1958) but differ in that they are almost horizontal and the septal pillar which bears them is considerably higher than 
in the two other species. Moreover, Platidia differs widely from the Kraussinidae in shell shape and beak characters.

Beecher (I893) gave among the diagnostic characters of the Terebratellidae King emend. 'cirri directed inwardly during larval stages', in contrast to the Terebratulidae Gray in which it was said 'cirri directed outwards in larval stages', that is in stages when the lophophore is either trocholophous or early schizolophous. Thomson (1927, pp. 180, 202) followed Beecher in making this supposed difference between the direction of the cirri or filaments in young stages one of the chief diagnostic differences between the two families, and this has been repeated by later workers.

Beecher's figures of the trocholophous and early schizolophous stages of Dallinella (= Terebratalia) obsoleta (I893, pl. ii, figs. IO, II, I2) were, he stated (1895, in the legends on p. 398), 'drawn from specimens which had been dried and afterwards expanded by soaking in water, and then stained and prepared for mounting. The original proportions and relations of the parts may be therefore somewhat altered'.

In the contracted state as when the valves of the living animal are first separated, or the animal is preserved without narcotizing, the filaments in the trocholophous and early schizolophous stages in terebratellaceans are as shown by Beecher, but when the animal is feeding with the shell gaping and lophophore expanded the filaments are directed ventrally and outwards, as may be seen from the figures of Platidia davidsoni, and P. anomioides accompanying this paper and from those of Pumilus antiquatus (Atkins, 1958). This has also been found to be so in Argyrotheca cordata, Megathyris detruncata, Pantellaria echinata, Terebratalia transversa and Terebratella inconspicua, and no doubt occurs also in Macandrevia cranium but unfortunately the very young of this species have so far only been seen preserved. Accounts are in preparation of the growth stages of most of these species and also of those of certain other brachiopods.

\section{THE CILIARY FEEDING MECHANISM OF PLATIDIA}

Work on the ciliary feeding mechanism of Platidia was done on P. davidsoni, which, being dredged from only 45 to $48 \mathrm{fm}$, survived well in the laboratory tanks. After separating the valves, the lophophore soon expanded and in one, perhaps exceptional, instance remained in good condition for Io days at temperatures of $13^{\circ}$ to $15.6^{\circ} \mathrm{C}$, with the lateral cilia beating rapidly with a good metachronal wave. This species was found to narcotize easily with stovaine one drop of $\mathrm{I} \%$ stovaine being added to a watch-glass of sea water at intervals. $P$. anomioides, dredged from 400 to 405 fathoms was on the contrary difficult to deal with.

P. davidsoni usually, although not always, lifts the shell at an angle from the substratum, so that it is raised I to $2 \mathrm{~mm}$ anteriorly, preparatory to opening 
the valves, uncoiling the filaments, ready for feeding. It can also shift the shell a little sideways in spite of its very short stalk.

In a normally feeding animal the valves gape fairly widely to an angle of $45^{\circ}$ or more. A large specimen of some $6 \mathrm{~mm}$ in length was seen to have an anterior gape of 3 to $3.5 \mathrm{~mm}$, and the lower, dorsal, valve was lifted from the substratum about $2 \mathrm{~mm}$ in front.

The lophophore as seen through the gape has the appearance of a plectolophe, but the short spiral arm in the expanded state is almost entirely ventral to the lateral arms. The dorsal filaments of the lateral arms extend to the edge of the dorsal valve: the ventral filaments usually appear to hang down toward the lower, dorsal valve-that is they do not touch on the edge of the ventral mantle as in other brachiopods observed-so that the inhalant current is drawn in somewhat dorsally and the exhalant current leaves the shell over a wider area than in most brachiopods with plectolophous lophophores. The correct position of the filaments cannot be shown in an opened animal.

The filaments on opposite sides of the short spiral arm either touch at their tips, interdigitate, or a slight space is left between the tips, which then appear to touch on the ventral mantle.

\section{The ciliation of the lophophore and the mantle}

The body of the lophophore is entirely ciliated-except possibly for mucous cells-as indicated by the movement of particles.

On the filaments the ciliation is in three main tracts, a frontal and paired lateral tracts.

The frontal cilia (f.c., Fig. I5) are about $20 \mu$ long. They appeared to be all alike, as seen in life across the frontal surface, when an inner filament with ridged frontal surface was bent sharply outwards. These cilia, as in other brachiopods examined, seem to be capable of reversing the direction of their beat (Atkins, 1956, 1958).

The lateral, current-producing, cilia (l.c., Fig. I5) are some $30 \mu$ long. They beat across the length of the filaments from the frontal to the abfrontal surface. The metachronal wave is of the type termed dexioplectic (KnightJones, 1954).

Sparse abfrontal cilia occur but do not appear to be effective, as no current could be demonstrated.

\section{The ciliary currents}

On the outer abfrontal surfaces of the lateral and spiral arms currents pass toward the bases of the filaments, although no abfrontal currents on the latter could be demonstrated.

The floor, or brachial membrane, of the lateral arms has currents passing toward the median line and posteriorly in the direction of the mouth. 
On the posterior and lateral regions of the large oral disc currents are directed toward the food groove. On the anterior region of the disc they are anterior in direction and particles pass off into the exhalant current.

The general direction of the currents is anteriorly on the ventral mantle. Over the middle region of the valve, that is lying to the inner side of the gonads, currents pass into an anteriorly directed current in the mid line. To the outer side of the gonads currents pass somewhat laterally and anteriorly into a submarginal anteriorly directed current. In fact over the gonads currents pass in opposite directions, toward the mid line and laterally. Currents on the dorsal mantle are similar in direction.

On the anterior body wall currents on each side of the septal pillar pass dorsally and anteriorly, and when no exhalant current is evident particles collect at the base of the septal pillar. This material would no doubt be lifted into the strong exhalant current when this is working.

In the young stages of the lophophore, trocholophous and early schizolophous, the inhalant current produced by the lateral cilia on the filaments, passes into the bell-shaped lophophore (Fig. 3B) and escapes between the filaments all around as previously described in Terebratulina retusa and Pumilus antiquatus (Atkins, 1956, 1958). As the invagination of the schizolophe deepens the inhalant current becomes divided into two and a narrow excurrent channel is present between the two lobes of the schizolophe, as in the adult Pumilus.

As in plectolophes generally the inhalant currents are lateral and paired and the exhalant single and median.

Platidia davidsoni was unusual in that the lateral cilia continued beating with a good metachronal wave for several days after separation of the valves. This allowed of some observations being made on them. If a filament is suddenly coiled, while the laterals are beating, they slow or stop, and as the filament is uncoiled they begin beating again. When the laterals are active there are no momentary intermissions, such as occur in lamellibranchs several times in a minute (Lucas, I931, pp. I57-8; Atkins, 1936, pp. 295-6), although they may stop for varying periods on some filaments or parts of filaments. The lateral cilia of brachiopods will evidently remain stationary for considerable periods, for at times animals will gape without detectable currents entering or leaving the shell cavity.

On the frontal surfaces of the filaments particles are conveyed by the cilia either toward the base and eventually to the mouth, or toward the tip to be rejected to the outside of the shell, according to the size and quantity provided (Atkins, 1956).

My thanks are due to the Captain and crew of R.V. 'Sarsia' who dredged the Platidia and to those members of the scientific staff, particularly to 
Dr A. J. Southward and Mr G. R. Foster, who were in charge of the scientific work and took care of the brachiopods for me.

Mr G. F. Elliott kindly read the manuscript. A grant from the Browne Fund of the Royal Society and a London University table made the work possible.

\section{SUMMARY}

Platidia davidsoni and P. anomioides dredged by R.V. 'Sarsia' have been examined living. The adult lophophore in both is shown to be a somewhat modified plectolophe, the spiral arm short with but one coil. In P. anomioides the brachial support consists of complete descending branches, growing from both crura and septum, and very short ascending branches arising from the apex of the septal pillar. The whole apparatus reaches only to the centre of the oral disc. In $P$. davidsoni the brachial support is much reduced: descending branches are absent; ascending branches, however, are larger than in $P$. anomioides. In both the main support of the lophophore is by spicules.

Full series of growth stages of the lophophore and its support of both species are described and figured for the first time. The growth of the lip of the food groove by extension of a small preoral lobe is described. The structure of the lophophore of $P$. davidsoni has been investigated by sectioning.

It is suggested that the Terebratula seminulum of Philippi 1836 is an immature stage of Platidia anomioides.

The value as a diagnostic character between terebratulaceans and terebratellaceans of 'filaments directed outwards' and 'filaments directed inwards up to the schizolophous stage' is commented on.

The ciliary feeding mechanism of $P$. davidsoni is briefly described.

\section{REFERENCES}

Atrins, D., I936. On the ciliary mechanisms and interrelationships of lamellibranchs. Pt. I. Quart. F. micr. Sci., Vol. 79, pp. 181-308.

- 1956. Ciliary feeding mechanisms of brachiopods. Nature, Lond., Vol. I77, pp. 706-7.

- 1958. A new species and genus of Kraussinidae (Brachiopoda) with a note on feeding. Proc. zool. Soc. Lond., Vol. I3I, pp. 559-8I.

- 1959. A new species of Platidia (Brachiopoda) from the La Chapelle Bank region. F. mar biol. Ass. U.K., Vol. 38, pp. 133-42.

BEECHER, C. E., I893. Revision of the families of loop-bearing Brachiopoda. Trans. Conn. Acad. Arts Sci., Vol. 9, pp. 376-91.

- 1895. The development of Terebratalia obsoleta Dall. Trans. Conn. Acad. Arts Sci., Vol. 9, pp. 392-9.

Costa, O. G., I852. Fauna del Regno di Napoli (Not seen.)

DALL, W. H., I92I. Annotated list of the recent Brachiopoda in the collection of the United States National Museum, with descriptions of thirty-three new forms. Proc. U.S. nat. Mus., Vol. 57, pp. 26I-377.

DAvidson, T., I852a. Sketch of a classification of recent Brachiopoda; based upon internal organization. Ann. Mag. nat. Hist., Ser. 2, Vol. 9, pp. 36I-77. 
- $1852 b$. Additions and corrections to Mr Davidson's paper on the classification of the Brachiopoda. Ann. Mag. nat. Hist., Ser. 2, Vol. 9, p. 5 I4.

- 1852 c. Descriptions of a few new recent species of Brachiopoda. Proc. zool. Soc. Lond., I852 (Part 20), pp. 75-83.

- 1880. Report on the Brachiopoda dredged by H.M.S. 'Challenger' during the years I873-1876. 'Challenger' Rep., Vol. I, pp. I-67.

- 1887. A monograph of recent Brachiopoda. Part II. Trans. Linn. Soc. Lond. (Zool.), Ser. 2, Vol. 4, pp. 75-182.

Elliotr, G. F., I949. The brachial development of Kraussina (Brachiopoda). Ann. Mag. nat. Hist., Ser. 12, Vol. 2, pp. 538-46.

Eudes Deslongchamps, E., 1855. On a new species of Morrisia. Ann. Mag. nat. Hist., Ser. 2, Vol. 16, pp. 443-4.

Fischer, P., 1872. Brachiopodes des côtes océaniques de France. F. Conchyliol., T. 20 , pp. $160-4$.

— I873. Faune conchyliologique marine du department de la Gironde et des côtes du sud-ouest de la France. Act. Soc. linn. Bordeaux, T. 29, (Sér. 3, T. 9), pp. 193-255.

FisCHER, P. \& OEHLERT, D.-P., I89I. Brachiopodes. Expéd. sci. Travailleur et Talisman, I40 pp.

Hancock, A., 1858. On the organization of the Brachiopoda. Phil. Trans., Vol. I48, pp. 79I-869.

Jefrereys, J. G., 1878. On the Mollusca procured during the 'Lightening' and 'Porcupine' Expeditions, 1868-70. (Part I). Proc. zool. Soc. Lond., I878, pp. 393-416.

KNIGHT-JoNES, E. W., I954. Relations between metachronism and the direction of ciliary beat in Metazoa. Quart. F. micr. Sci., Vol. 95, pp. 503-21.

LUCAS, A. M., I93I. An investigation of the nervous system as a possible factor in the regulation of ciliary activity of the lamellibranch gill. $\mathcal{F}$. Morph., Vol. 5I, pp. $147-93$.

Massy, A. L., 1925. The Brachiopoda of the coasts of Ireland. Proc. R. Irish Acad., Vol. 37, pp. 37-46.

MORSE. E. S., I87I. On the early stages of Terebratulina septentrionalis (Couthouy). Ann. Mag. nat. Hist., Ser. 4, Vol. 8, pp. 4I4-27.

Percival, E., 1944. A contribution to the life-history of the brachiopod, Terebratella inconspicua Sowerby. Trans. roy. Soc. N.Z., Vol. 74, pp I-23.

PhILIPPI, R. A., I836. Enumeratio Molluscorum Siciliae. Vol. I.

- I844. Enumeratio Molluscorum Siciliae, Vol. 2.

Prenant, M., 1928. Notes histologiques sur Terebratulina caput-serpentis L. Bull. Soc. zool. Fr., T. 53, pp. $113-25$.

RICHARDS, J. R., I952. The ciliary feeding mechanism of Neothyris lenticularis (Deshayes). F. Morph., Vol. 90, pp. 65-92.

SENN, E., 1934. Die Geschlechtsverhältnisse der Brachiopoden, im besonderen die Spermato- und Oogenese der Gattung Lingula. Acta zool., Stockh., Bd. 15, pp. I-I52.

Thomson, J. A., I927. Brachiopod morphology and genera (recent and tertiary). N.Z. Bd Sci. Art, Manual 7.

WiLliams, A., I956. The calcareous shell of the Brachiopoda and its importance to their classification. Biol. Rev., Vol. 3I pp. 243-87. 